\title{
Heat Recovery from Wastewater-A Review of Available Resource
}

\author{
Himanshu Nagpal (D, Jan Spriet (D), Madhu Krishna Murali (D) and Aonghus McNabola *(D) \\ Department of Civil, Structural \& Environmental Engineering, Trinity College Dublin, Dublin, Ireland; \\ nagpalh@tcd.ie (H.N.); sprietj@tcd.ie (J.S.); MURALIM@tcd.ie (M.K.M.) \\ * Correspondence: amcnabol@tcd.ie
}

check for updates

Citation: Nagpal, H.; Spriet, J.; Krishna Murali, M.; McNabola, A. Heat Recovery from Wastewater-A Review of Available Resource. Water 2021, 13, 1274. https://doi.org/ 10.3390/w13091274

Academic Editor: José Alberto Herrera-Melián

Received: 7 April 2021

Accepted: 27 April 2021

Published: 30 April 2021

Publisher's Note: MDPI stays neutral with regard to jurisdictional claims in published maps and institutional affiliations.

Copyright: (C) 2021 by the authors. Licensee MDPI, Basel, Switzerland. This article is an open access article distributed under the terms and conditions of the Creative Commons Attribution (CC BY) license (https:// creativecommons.org/licenses/by/ $4.0 /)$.

\begin{abstract}
The EU Directive 2018/2001 recognized wastewater as a renewable heat source. Wastewater from domestic, industrial and commercial developments maintains considerable amounts of thermal energy after discharging into the sewer system. It is possible to recover this heat by using technologies like heat exchangers and heat pumps; and to reuse it to satisfy heating demands. This paper presents a review of the literature on wastewater heat recovery (WWHR) and its potential at different scales within the sewer system, including the component level, building level, sewer pipe network level, and wastewater treatment plant (WWTP) level. A systematic review is provided of the benefits and challenges of WWHR across each of these levels taking into consideration technical, economic and environmental aspects. This study analyzes important attributes of WWHR such as temperature and flow dynamics of the sewer system, impacts of WWHR on the environment, and legal regulations involved. Existing gaps in the WWHR field are also identified. It is concluded that WWHR has a significant potential to supply clean energy at a scale ranging from buildings to large communities and districts. Further attention to WWHR is needed from the research community, policymakers and other stakeholders to realize the full potential of this valuable renewable heat source.
\end{abstract}

Keywords: wastewater heat recovery; shower water heat recovery; wastewater heat exchanger; heat pump low-grade heat

\section{Introduction}

The European Union (EU) has established a target to achieve a $40 \%$ reduction in greenhouse gas (GHG) emissions (from 1990 levels), and the renewable energy share of the union should be increased to $32 \%$ of total energy generation [1]. Under the regulation on the governance of the energy union and climate action (EU/2018/1999), EU member states have established a 10-year integrated national energy and climate plan (NECP) [2]. Under these circumstances, renewable sources of energy have been of great interest in recent years. The EU Directive 2018/2001 [3] specified wastewater as a renewable heat source in compliance with the European environmental goals. Moreover, under the European Green Deal Investment Plan, member states will be provided supportive aid to implement measures like the re-use of waste heat [4].

The wastewater in domestic, industrial, or commercial buildings maintains considerable thermal energy quantities, which is discharged to the sewer system with temperature ranging from 10 to $25^{\circ} \mathrm{C}$. It is estimated that $6000 \mathrm{GWh}$ per year of thermal energy is lost in sewers in Switzerland [5], equivalent to $7 \%$ of country's total heating demand. Wastewater in sewer pipes in Germany is estimated to contain enough energy to heat 2 million homes [6]. This resource can be exploited through heat exchangers and heat pump technologies, applied at different points in the sewer system, from end-user to water treatment, that is, at the component level, in buildings, in public sewers, and at WWTPs. These locations have their respective advantages and disadvantages concerning their energy, economic and environmental prospects. For example, low heat loss is present at component level WWHR, while greater heat density is available at WWTPs. 
Existing papers in the literature have studied different elements of WWHR in different settings, such as heat recovery at different locations within the sewer system, with heat exchangers, with a combination of heat exchangers and heat pumps, examining the costeffectiveness, and environmental impacts, and so forth. However, a synthesis of the potential of heat recovery across the sewer system's entire water cycle, from leaving the drain of a building to discharge into water bodies after treatment, is missing. Such a synthesis would be essential to present the complete picture of energy availability in wastewater in the sewer system and the advantages, disadvantages, and challenges of its exploitation in different locations, given its recent recognition as an essential renewable heat source.

This paper presents a comprehensive review of the literature on WWHR at different points along the sewer system, from user discharge to water treatment. The review outlines state-of-the-art in sewer water temperature dynamics, the environmental impact of WWHR and the legal regulations involved. Heat exchanger design, type, configuration, performance and fouling in WWHR settings are not considered in this paper, as other review papers have addressed these [7-9].

The review paper is systematically divided into WWHR at different levels along the water cycle addressing the benefit and challenges of each. The interested stakeholder can gain important insights into the level of heat recovery they are interested in. Furthermore, the work also highlights other important aspects of WWHR, such as economic analysis and environmental impact, which can assist the policymakers in making relevant decisions. For the research community, the work emphasizes the research gaps in the field and suggests possible avenues for future research.

\section{Methodology}

In identifying the sources for the literature review, an initial search with Google Scholar search system was performed to understand the available literature with the following keywords-wastewater heat recovery, drain water heat recovery, and wastewater source heat pump. The majority of the articles from Google Scholar search were found to be published by Elsevier. Therefore, the ScienceDirect database that contains full-text articles from journals and books published by Elsevier, and the Scopus database were used to narrow down the literature search. Furthermore, the artificial-intelligence-based search system Semantic Scholar was also used with the same keyword search. The search resulted in similar research data with some additional articles and dissertations. In addition to the databases and search systems, some literature was identified using the well-known snowball method, that is, to look for research data in the bibliography and citations of the primary literature.

The entire database of 154 research items was prepared, which included research articles, dissertations and technical reports. The abstract and summary of each research item were carefully analyzed to narrow down the results that fit the purpose of this literature review. The research data were further divided into categories based upon the structure of the present work, such as research items belonging to different levels of WWHR, investigating wastewater temperature and flow modelling, addressing environmental impacts and so forth.

\section{Wastewater Heat Recovery}

Wastewater is "used water from any combination of domestic, industrial, commercial or agricultural activities, surface runoff/stormwater, and any sewer inflow/infiltration" [10]. Almost $20 \%$ of energy use in the domestic sector is associated with water heating for various purposes (e.g., shower, bath, dishwasher, washing machine, cooking, etc.) [11]. Wastewater, therefore, contains a significant amount of heat energy that can be recovered and used for preheating the cold-water supply in a building or space-heating, depending upon the magnitude of heat available. The heat embedded in wastewater depends upon 
its temperature and flow rate. The content of available heat for recovery from wastewater can be calculated using the heat transfer equation:

$$
\dot{Q}=\dot{m} c_{p} \Delta T
$$

where, $\dot{Q}$ is the recovered heat content per unit time, $\dot{m}$ is the mass flow rate of wastewater, $c_{p}$ is its specific heat capacity, $\rho$ is the density of wastewater, and $\Delta T$ is the temperature change of wastewater due to heat recovery. As per Equation (1), a higher flow rate and temperature of wastewater results in a higher potential for heat recovery.

Independent from the heat recovery system type, two main components may be involved in WWHR: a heat exchanger and heat pump. Although in some situations, heat may be recovered only using a heat exchanger, typically when the average temperature of the wastewater is higher than $30^{\circ} \mathrm{C}$ (domestic shower settings). A heat exchanger is a device that facilitates the transfer of internal thermal energy between two fluids while avoiding the mixing of the two. It is a passive technology that does not require any external energy source. Some commonly used heat exchanger types in WWHR applications include double-pipe parallel flow, double-pipe counterflow, shell-and-tube, and plate-and-frame heat exchanger. Heat exchanger types and their performance in WWHR applications are discussed in detail by Culha et al. [9].

A heat pump is a technology that uses electricity and the reverse refrigeration cycle to transfer heat from one place to another [12]. Heat pumps require a low-temperature energy source and convert this low-grade heat to usable heating energy by mechanical work. In the context of WWHR, wastewater serves as the low-grade heat source for the heat pump. A heat pump can work in both heating and cooling modes. In cooling mode, the ambient air of the space which needs cooling acts as a source, and heat is extracted from it, leading to space-cooling. Heat pump types and their performance in WWHR applications are discussed in detail by Hepbasli et al. [7].

\section{Energy Recovery Options}

There are four main possible locations within the sewer system for energy recovery from wastewater: (i) at the component level; (ii) at building level; (iii) in the sewer pipe network, and (iv) from WWTPs. Figure 1 shows these possible options of WWHR.

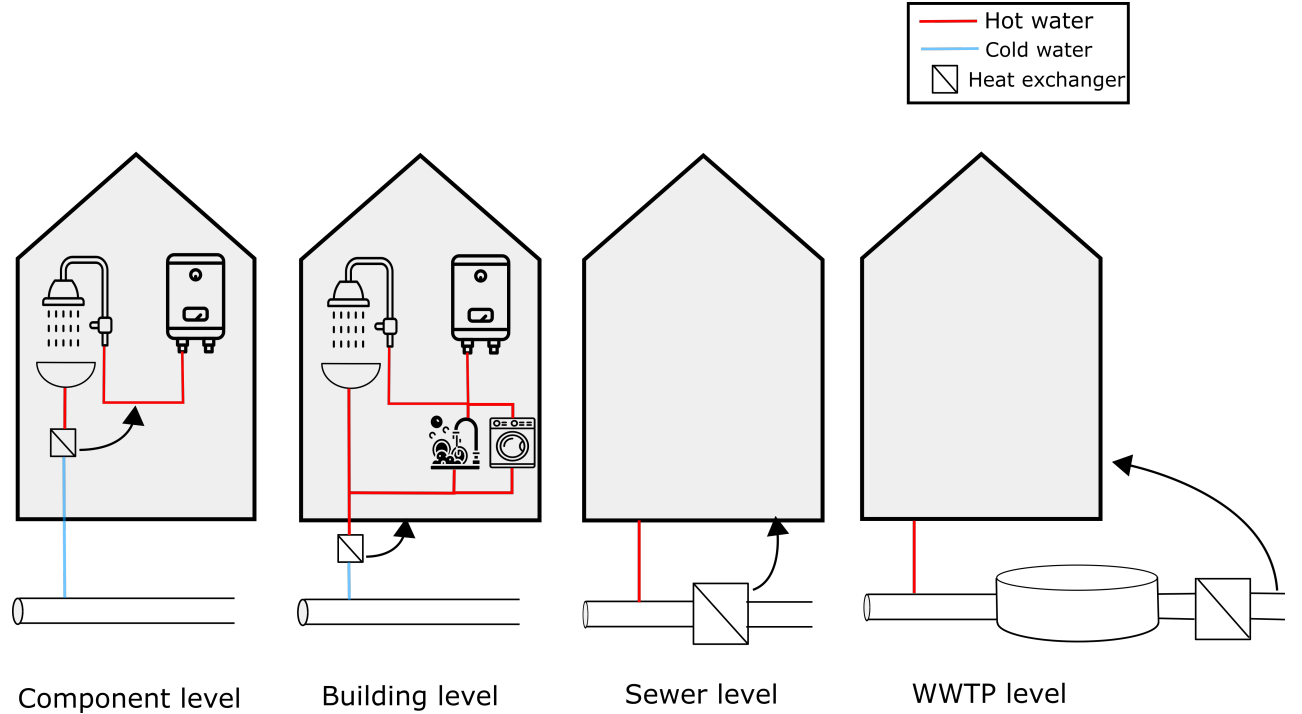

Figure 1. Possible options of heat recovery from wastewater [5].

\subsection{Heat Recovery at Component Level}

At this level of WWHR, heat is recovered from wastewater directly after it is produced in specific activities relating to a single component (e.g., showering, cooking, food 
processing, etc.). Heat is extracted using a heat exchanger directly after the component used in the activity. The recovered heat may be used to preheat incoming cold-water, as in domestic or commercial shower facilities, or be used in conjunction with a heat pump for other purposes. Figure 2 shows the basic working principle of a vertical counter-flow heat exchanger.

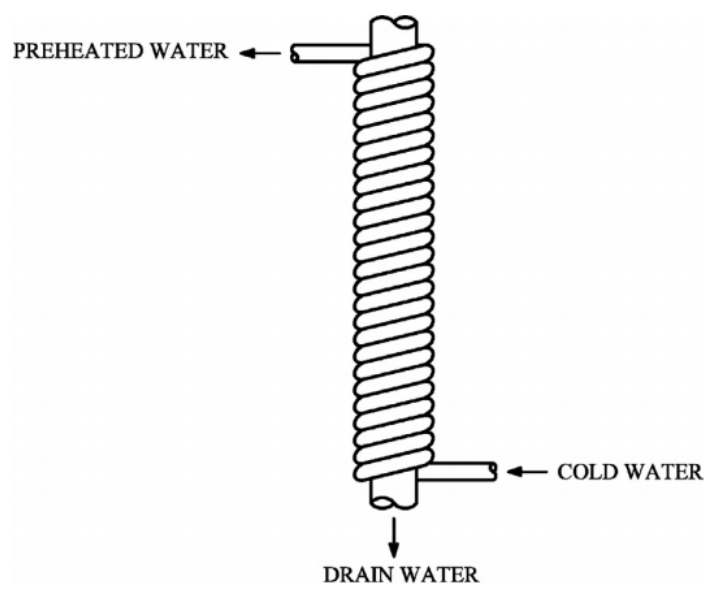

Figure 2. Basic working principle diagram of a vertical WWHR unit [13].

Shower water heat recovery is the most common application seen in practice at this level. This application has the advantage of a continuous simultaneous counter flow of wastewater and incoming cold-water supply for use in the shower. Therefore, heat recovered here can be achieved with high effectiveness, and there is no time lag present between waste heat availability and heat demand for showering, eliminating the need for heat storage and resulting losses [14]. A general schematic of shower water heat recovery is shown in Figure 3.

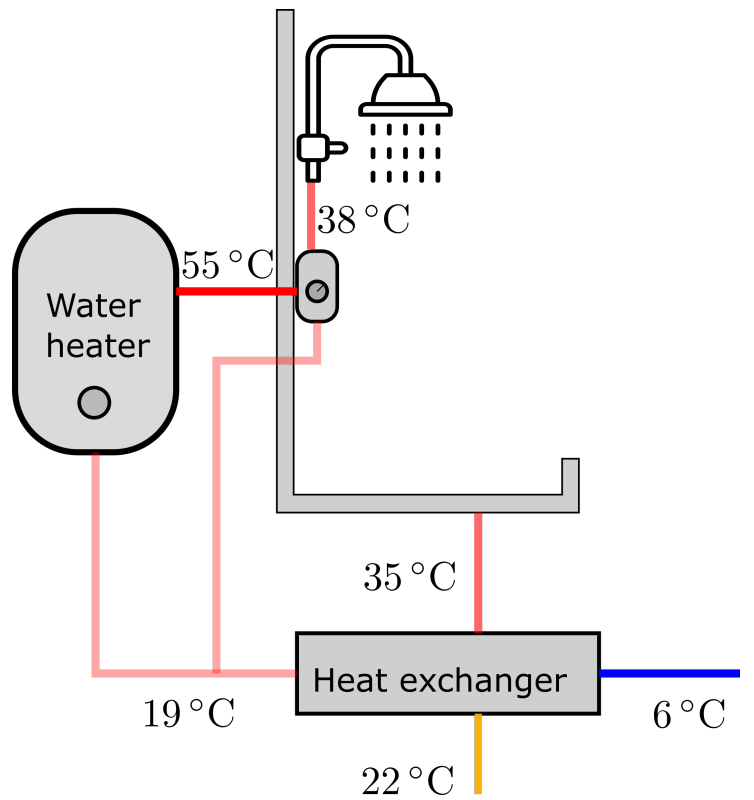

Figure 3. General schematic of shower water heat recovery [15].

In real applications, heat exchangers are placed under the shower tray in either horizontal or vertical orientations. Both have their respective advantages and disadvantages. In the vertical configuration, the wastewater is discharged as a falling film flow, whereas in the horizontal orientation, water flows at the bottom of the pipe. Therefore, the effective surface area over which heat is exchanged is larger in the vertical orientation, which leads 
to higher efficiency [16]. Wong et al. [17] analyzed shower water heat recovery in high-rise residential buildings in Hong Kong. The study investigated the installation of a single-pass counter-flow heat exchanger installed beneath shower drains in the horizontal configuration. The result showed an annual energy saving of $4-15 \%$ from shower water heat recovery. The savings were dependent upon drainage pipe diameter and length, which governs the effective area of heat exchange surface.

An experimental study conducted at the Canadian Center of Housing Technology analyzed the performance of five vertical heat exchangers for WWHR at component level [13]. The results showed a $9 \%$ to $27 \%$ reduced natural gas usage for hot water preparation in domestic shower applications. The energy savings increased with the number of showers and lower temperature of the incoming cold-water supply. Another critical factor is the configuration of the WWHR system. The energy savings are higher when recovered energy is used to heat the water flowing into the hot water tank and shower valve, compared to heating only the water entering the hot water tank. Similar results for such configurations have been observed by Tomlinson [18]. Tomlinson [18] argued that the overall water flow is balanced in the first configuration, that is, flow on both sides of the heat exchanger are equal, resulting in higher heat recovery.

On the other hand, a major disadvantage of vertical heat exchangers is the large space requirements for their installation, requiring around 1-2 $\mathrm{m}$ of vertical space below the shower tray. In many existing buildings, such facilities are not possible due to space limitations. Besides, longer heat recovery units are preferred for better efficiency, which is more expensive and space-consuming. Consequently, researchers have also investigated improving the horizontal heat exchanger's design to achieve higher effectiveness $[19,20]$. McNabola and Shields [20] proposed a new horizontal WWHR heat exchanger design to maximize the heat exchange between wastewater and cold-water supply. The design was based upon placing the cold-water supply pipe into the wastewater pipe, thus increasing the contact surface area. The results showed that the effectiveness of over $50 \%$ could be achieved for the proposed design, which is comparable to some existing vertical WWHR units. Currently, several proprietary horizontal WWHR heat exchanger also exists in the market with similar effectiveness to vertical WWHR heat exchangers [21].

Another study investigated the possibility of using a storage-type WWHR unit [22]. In this case, wastewater is stored in an insulated steel tank and cold-water pass through a copper coil immersed into wastewater. The proposed system is smaller in height than a vertical WWHR unit and can recover $34 \%$ to $60 \%$ of available energy in wastewater. However, such an implementation would not be economically viable due to the additional tank and insulation cost. Such a design could be successful combined with a heat pump system [23-25].

For overall viability of a WWHR component level application, it is vital to consider the financial analysis of the system [26]. The economic viability of the WWHR unit not only depends upon heat exchanger characteristics but also can depend upon user behaviour like shower length, shower head flow rate, desired water temperature, number of showers and so forth [27]. Słyś and Kordana [28] analyzed the effect of shower length and shower head flow rate upon the payback period and net present value (NPV) of a vertical WWHR heat exchanger. The study observed that with increases in shower length and shower head flow rate, that is, higher water consumption, NPV of the WWHR system increases. The considered WWHR unit's payback period, under the same flow rate conditions, decreased by $66 \%$ with an increase in shower length from 5 to $12 \mathrm{~min}$. The study concluded that WWHR units could have significant financial savings in dwellings with large amounts of water usage.

Apart from additional space requirements for WWHR, another challenge is that such installations can be cost-effective only when fitting a new bathroom or renovating an existing one. The additional cost of retrofitting the WWHR system in the existing bathrooms and changing the water pipe infrastructure for the sole purpose of heat recovery can increase the device's overall payback period. 
Another major issue of the WWHR system is the fouling of the heat exchanger. Fouling is the accumulation of unwanted deposits on the surface of heat exchanger [29]. It increases the heat exchanger's thermal resistance, generally referred to as fouling resistance. Due to fouling resistance, the heat exchanger's heat capability decreases, leading to fewer energy savings. Fouling also adds additional maintenance cost to the device. Evidently, the horizontal heat exchangers are more prone to fouling than vertical heat exchangers due to the continuous build-up of unwanted deposits on the horizontal plate. There is a lack of information on fouling and maintenance of horizontal WWHR units for showers. One study performed by a horizontal WWHR unit manufacturer observed that after applying a large amount of shampoo, soap and hair-conditioner on the heat exchanger surface and keeping it overnight, there was a performance drop of 5.5\% for only first $10 \mathrm{~min}$ for the device [30]. The study also reported the same performance for the device over a two years interval. Future work is required to examine the fouling performance of a range of heat exchanger types for shower applications.

Apart from the shower systems, wastewater heat can be recovered from other components, such as dishwashers and washing machines. These components discharge wastewater at fairly high temperatures; for example, exit water temperature for a typical household dishwasher ranges from $19{ }^{\circ} \mathrm{C}$ to $61^{\circ} \mathrm{C}$ depending upon the washing stage [31]. The water consumption during the whole washing cycle is around 331 . Paepe et al. [31] proposed a storage-based heat recovery system for domestic dishwashers and analyzed its technical and economic performance. The study showed a $25 \%$ reduction in total heating demand from the dishwasher with a payback period of 6 years.

Large scale components such as dishwashers in industrial kitchens and washing machines in launderettes use a large amount of hot water thus can have significant potential for WWHR. Wemhoff et al. [32] analyzed the viability of WWHR for dishwashers in a university's dining facility in Philadelphia. The study calculated a payback period of 2 years for the proposed installation of a $146 \mathrm{~kW}$ shell-and-tube heat exchanger. The annual source pollution reduction of $13 \mathrm{~kg} \mathrm{SO}_{2}, 6.5 \mathrm{~kg} \mathrm{NO}_{x}$ and 6.5 metric tons $\mathrm{CO}_{2}$ was shown.

Adhikari [33] performed a feasibility study to examine WWHR in a public laundry facility with two washing machines with average wastewater temperature and flow of $60{ }^{\circ} \mathrm{C}$ and $0.11 \mathrm{~kg} / \mathrm{s}$. The study reported $103 \mathrm{MWh} /$ year of heat recovery from laundry facility's wastewater leading to almost $€ 6371$ of economic savings.

A myriad of other hot wastewater generating components exist in domestic, commercial and industrial settings, aside from showers, dishwashers or washing machine, for example, sinks in hair salons, swimming pools/spa applications, food processing, and so forth. These have received scant attention in the literature to date.

\subsection{Heat Recovery at Building Level}

At this level, heat is recovered from the collective wastewater discharge from a single whole building is considered. The wastewater flow and temperature characteristics of this discharge depend upon building type. Wastewater in domestic building can maintain a temperature of $10-25^{\circ} \mathrm{C}$ over the year [23]. The energy savings from WWHR at the building level can be higher when compared to the individual component level due to the higher volume of wastewater and accumulation of multiple hot water activities [28]. However, discharge at the building level also includes cold wastewater in the mix, which reduces energy potential. At this level, to perform heat recovery, wastewater is commonly collected in a holding tank, and heat is recovered using a heat exchanger [33,34] or water source heat pump [23-25]. For fouling prevention, usually a grease trap system is used to intercept debris in wastewater. If the recovered heat is not immediately used, it can be stored in a hot water tank (HWT) for later use. A general schematic diagram of WWHR with a heat pump is shown in Figure 4. Researchers have investigated the potential of WWHR at the building scale with numerical feasibility studies, and experimental labscale approaches $[24,25,35-39]$. 


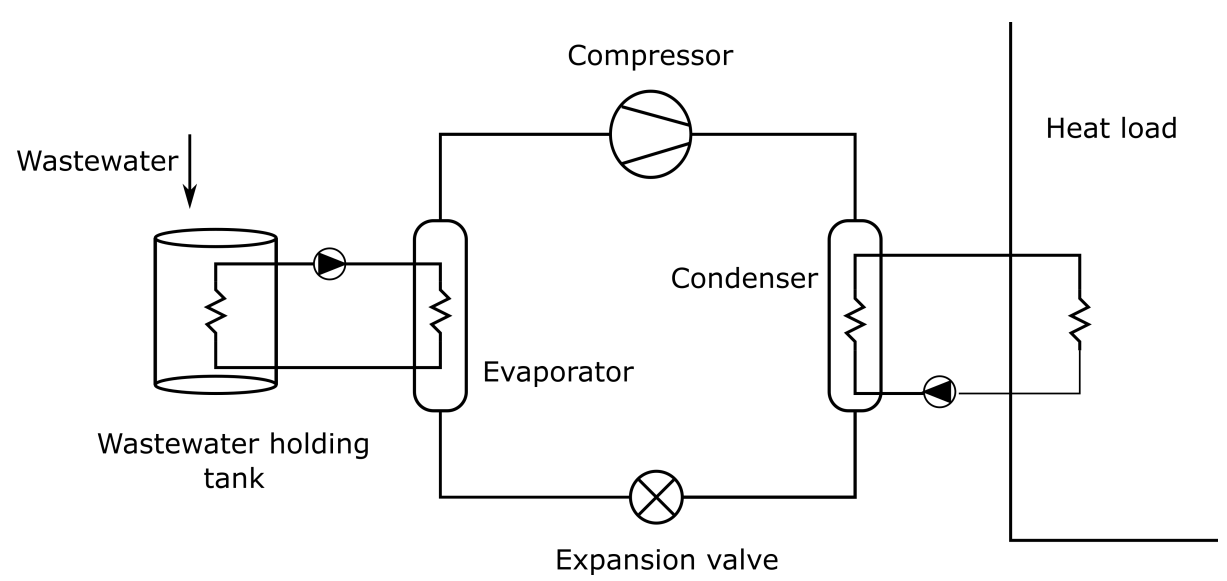

Figure 4. Schematic diagram of WWHR with heat pump.

\subsubsection{Residential Dwellings}

In residential houses, complexes and apartments, wastewater amounts depend upon the number of residents in a dwelling and their water-usage activities. Due to the mixing of wastewater from different water sources in the building, including cold-water equipment, wastewater temperature is often lower than it can be at the individual hot water component level [40]. Ni et al. [24] presented a feasibility study for WWHR in residential developments with a heat pump and evaluated the total source energy consumption of the building for space heating and hot water heating with and without WWHR. The results demonstrated a $17-58 \%$ reduction in total energy usage depending upon the building's location. However, the study lacked any economic analysis of system installation, which is important for assessing financial viability and its likely penetration in practice.

Heat pump technology can be quite expensive and may not be financially suitable for single-family residences. Furthermore, wastewater flow has been found to be insufficient and containing too much variation in single residences to make such system economically efficient [41]. Spriet and McNabola [23] presented a numerical feasibility study for WWHR with heat pump in a typical residential house (Ireland). The study observed energy savings of up to $42 \%$, similar magnitude to the findings of $\mathrm{Ni}$ et al. [24]. However, despite these impressive savings potential, due to the high capital cost of the technology, the Levelized Cost of energy increased by $120-130 \%$ compared to traditional heating systems, thus making the system not economically viable.

A reference guideline for economical use of WWHR with a heat pump at the building level is to have wastewater flow of at least 8000 to $10,000 \mathrm{~L} /$ day (equivalent to 60 people or 30 residential units) to be economically feasible [41]. Therefore, WWHR can have significant potential in residential buildings with a large number of residents, such as apartment buildings, multifamily complexes, hotels or student accommodation, and so forth. Alnahhal and Spremberg [40] presented a WWHR feasibility study for a 330 room student hostel in Berlin. Based on the wastewater flow, wastewater temperature and supply temperature measurements, the study showed a $30 \%$ reduction in hot water heating demand for the considered heat exchanger and heat pump specifications.

\subsubsection{Non-Residential Facilities}

Non-residential buildings like sports complexes [34], public showers [42] and commercial washing facilities [33] also produce large amounts of wastewater. Such facilities have stable heating demand throughout the year and have specific operation time; therefore, heat use and elimination are concentrated during those times. Ip and She [34] conducted an experimental study at a two-storey sports pavilion in the University of Brighton, UK. In this study, each shower was equipped with a single heat recovery pipe-vertical configuration for the first floor and horizontal configuration for the ground floor. The study demonstrated that the incoming cold-water supply could be preheated up to $10^{\circ} \mathrm{C}$ with WWHR, and a potential weekly saving of 40-119 $£$ was shown. 
Liu et al. [42] presented a numerical study for WWHR system with a heat pump in a public shower facility. The analysis was applied to a real building case with 50 shower nozzles. The study concluded that the total cost (initial and operating) of the WWHR system was $12 \%$ and $39 \%$ of the cost if the oil boiler and coal boilers were used, respectively. The economic saving shown in this study were significantly higher than those found in a single residential building. The possible explanations could be the facility's high wastewater volume, the assumption of an unrealistic shower time of $35 \mathrm{~min}$ per person, and disregarding the maintenance cost in calculations.

Other types of non-residential buildings such as offices, hotels [43], hospitals [44] and commercial kitchens/restaurants [45] also maintain good potential for WWHR. Again, the amount of energy recovery depends upon the wastewater characteristics in the building. Baek et al. [36] performed a feasibility study to analyze the possibility of using wastewater as a heat source for a heat pump at a hotel sauna service in South Korea. The study results predicted a yearly mean operating COP of the heat pump at 4.5-5.0 and reported that the heat pump could meet $90 \%$ of hot water demand. Spriet and McNabola [45] considered the installation of heat exchangers for WWHR in commercial kitchens in different hospitality sectors in the UK. This analysis reported a total financially feasible potential of approximately 1.24 TWh/yr from WWHR in the hospitality and foodservice sector in the UK, with the largest potential in health care outlets due to their large water consumption.

\subsubsection{Remarks}

There are several important issues which require more attention from the research community at the building level. These issues are crucial for the practical implementation of WWHR systems in actual buildings. They fall into the categories of: (i) resource potential, (ii) practical implementation, and (iii) WWHR operation. Considering the potential size of the waste heat resource available at building level, there is a significant body of evidence for domestic buildings and a limited amount for certain commercial activities such as restaurants/cooking, launderettes, and so forth. However, there is limited evidence on the waste heat potential at buildings containing industrial activities (e.g., brewing, food processing, power production, cooling, etc.). More information is needed on heat availability at commercial buildings (hairdressers, hotels, restaurants, leisure centres, spas, etc.). Information on the amount of wastewater heat and the variation in this across seasons, climates, and building/business size and type is a crucial gap in identifying the heat inputs in the sewer system as a whole.

Practical implementation issues are often neglected in WWHR investigations of this nature. For example, the issue of the distance between the waste heat source and the existing heating facility or incoming cold water in a building, which often do not coincide, can be barriers to implementation. Retrofitting existing buildings with WWHR systems, in general, is a challenging issue that may often prevent the resource from practical exploitation. In some cases, the required space may not be available for such installations; in others, the water piping infrastructure has to be considerably altered, leading to additional costs.

Studies also often neglect the issue of the maintenance of WWHR systems which is evidently prone to fouling due to wastewater characteristics. Maintenance incurs a cost and also implies the reduced performance of heat exchangers and heat pumps with lower effectiveness and COP over time. Another issue mentioned by Spriet and McNabola [23] is that studies often present only high-level analyses of the potential of WWHR with inherent assumptions on the spatial and temporal variability of heat availability and demand and system performance. Assuming instantaneous consumption of waste heat and not considering the temporal mismatch between heat recovery and heat consumption overestimates the impact of WWHR. Assuming constant system performances regardless of waste heat temperature and flow, and neglecting the impact of fouling, similarly overestimates the impact of WWHR. Finally, there is also a lack of real-world or experimental demonstrations of WWHR in the literature at the building level. Most studies are theoretical in nature, and more research is required to investigate real-world applications. 


\subsection{Heat Recovery at Sewer Pipe Network Level}

WWHR from raw wastewater in public sewer pipe systems is a promising source of energy. Wastewater flow in sewer pipe systems is abundant and continuous throughout the year with yearly temperature of $10-20^{\circ} \mathrm{C}$, making sewer pipe wastewater an ideal source of heating/cooling for heat pumps throughout the year.

\subsubsection{Sewer Pipe Heat Recovery}

There are two possible ways of WWHR from the sewer pipe system; the first is to install a heat exchanger in the pipe bed as seen in Figure 5a and using heat pump for pumping this energy into a centralized heating system. The second option is to install an external heat exchanger above ground level. for this, a portion of sewer water flows into a screen to retain coarse solids, and the pre-screened wastewater is then pumped to the heat exchanger above the ground (Figure $5 b$ ). The heat exchanger is further connected to a heat pump evaporator. Both types of installations have been in operation in various European countries like Switzerland and Norway for many years [5] with thermal power ratings of installations ranging from $10 \mathrm{~kW}$ to $20 \mathrm{MW}$.

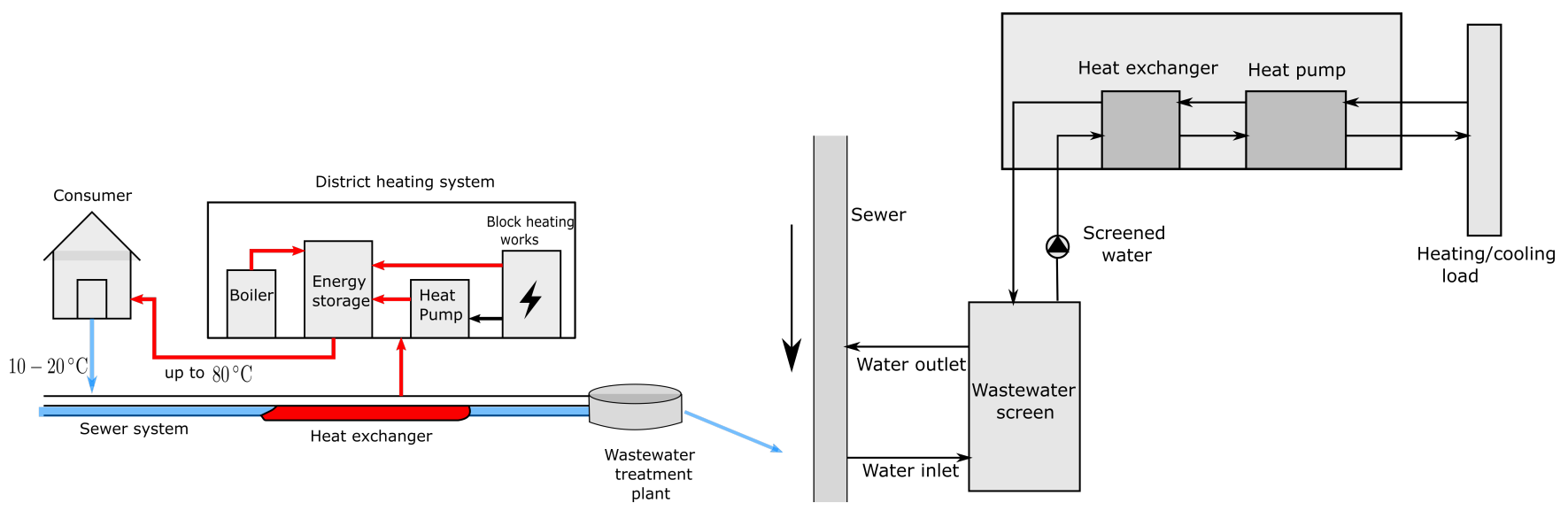

(a)

(b)

Figure 5. (a) WWHR with a heat exchanger in sewer bed; (b) External heat exchanger with upstream filtration [5].

In first option, the heat exchanger can either be separately placed into the sewer pipes bed, or a sewer pipe can be manufactured explicitly with an integrated heat exchanger in the sewer pipe wall. The advantage of this option is that no additional space is required for the installation. Also, wastewater does not have to be pumped out from the sewer. However, the system's maintenance is also not straight-forward, which may require permits since the temporary operation of the sewer line is suspended during maintenance. Further, some design preconditions need to be met; for example, minimum sewer diameter of $800 \mathrm{~mm}$, minimum wastewater flow of $30 \mathrm{~L} / \mathrm{s}$ and minimum wetted surface $0.8 \mathrm{~m}^{2}$ per meter length of sewer line [5]. Another major issue with such heat exchangers is fouling due to biofilm formulation and sediments in wastewater leading to fouling resistance, which can reduce the heat transfer efficiency of the heat exchanger by up to $50 \%$ [46]. Therefore, frequent maintenance and cleaning are required to remove any biofilm build-up.

For second option, the main advantage is independence of the system from the main sewer line; therefore, minimal interference with sewer operation. The installation and maintenance of the heat exchanger are easier. The cross-section and slope of the sewer system are irrelevant to the design specification of the system. However, the system requires pumping power to transport pre-screened wastewater to the heat exchanger, which increases overall energy demand. Also, additional space is required for such an installation. The heat exchanger is less prone to fouling because of the pre-screening of 
wastewater. In some cases, separate devices are installed to avoid and remove suspended solids, and feculences $[47,48]$.

\subsubsection{Energy Savings and Economical Potentials}

Preliminary feasibility studies have shown the significant energy saving potential of WWHR in sewer pipe networks. For example, Cipolla et al. [49] took flow and temperature measurements in sewer system of Bologna, Italy and demonstrated a thermal power potential of $74 \mathrm{~kW}$ with $3 \mathrm{~L} / \mathrm{s}$ of wastewater flow and a $5.9^{\circ} \mathrm{C}$ temperature drop. Sievers et al. [50] showed WWHR could provide $554 \mathrm{MWh}$ /year with wastewater temperature drop to $10^{\circ} \mathrm{C}$ in Hamburg, Germany.

Studies based upon existing WWHR systems in different parts of the world also present strong evidence of significant energy saving potential with up to $50 \%$ reduction in primary energy consumption $[47,48]$. Guo and Hendel [51] presented a field performance study of a WWHR system for a low carbon district in a suburb of Paris. The study results observed that the heat pump system supplied around $75 \%$ of heating energy throughout the year. The share of recovered energy represented $30-40 \%$ of monthly primary energy consumption. The installed system had four times less $\mathrm{CO}_{2}$ emissions than gas-only heating supply.

Apart from energy savings, the economic benefits of a WWHR system are an important factor in realizing the technology's overall viability. WWHR technology for sewer systems has not only high investment costs but operating, and maintenance costs are also significant. The economic success of such systems is dependent upon energy savings brought by the installation, which depends upon the following key points [5,52]:

- The payback period of WWHR will be higher when replacing a expensive fuel source compared to an inexpensive one.

- WWHR systems are more financially successful when heat demand is available throughout the year. The use of WWHR for longer periods results in more energy savings and decrease the payback period.

- Electricity is used in WWHR systems for heat pump compressor operation and other auxiliary components like pumps and accounts for the heat pump's operational cost. Low electricity prices will improve the economic feasibility of the system.

- WWHR systems are more financially successful at sites where a new heating/cooling system is being constructed or an existing installation is due to be replaced, decreasing overall investment capital and avoiding retrofitting costs.

- The distance between consumer and heat recovery location also influences the economical use of the WWHR system. The higher the distance between the two results in higher heat losses during transport, leading to greater operational costs.

Some research studies from literature are discussed in the context of the above points. Hrabová et al. [53] performed an economic assessment of a WWHR system comparing the overall cost of the system with a gas and electric boiler. WWHR achieved higher economic savings when replaced the electric boiler due to its high operational cost.

Pamminger et al. [54] performed a desk study to analyze sewer heat recovery potential in Melbourne, Australia. The study observed that current natural prices were too low and would have to increase by around $162 \%$ for commercial feasibility of the system.

The feasibility study presented in [55] highlighted the economic viability of WWHR for small scale neighbourhoods. Preliminary cost analysis in the study showed that the total cost of the WWHR system was $60 \%$ higher in comparison to a conventional gas boiler system at considered natural gas and electricity prices (The Netherlands).

While WWHR in sewer pipe systems is beneficial in terms of reducing the energy consumption and GHG emissions, on the other hand, it could negatively influence the treatment operation of wastewater in WWTP. This is because the wastewater temperature drops when wastewater heat is utilized; consequently, the temperature of influent wastewater in a WWTP may also reduce. This could lead to a reduction in the nitrification capacity of WWTP, which is a temperature-dependent process. Different countries have defined 
guidelines to ensure the efficient operation of WWTPs. For example, in Switzerland, the minimum temperature of influent wastewater needs to be $10^{\circ} \mathrm{C}[56]$.

\subsection{Heat Recovery at WWTP Level}

Another critical location for energy recovery from wastewater is at WWTPs. There are three possible heat recovery points at a WWTP-from raw wastewater before treatment, from partially treated water within the WWTP, and from effluent discharge after treatment. Heat recovery from raw wastewater is similar to recovering heat from within the sewer pipe system. At the WWTP, the influent's temperature and the available energy are highest, offering the greatest potential for WWHR. However, the water quality is the lowest, offering significant technical challenges in exploiting it. As we move through the WWTP, the temperature reduces and the water quality increases, whereby at the effluent discharge, the technical difficulty of recovering heat from raw wastewater is removed at the cost of a lower temperature fluid.

WWTPs process and treat large amounts of wastewater from sewers and then discharge into near water bodies on a daily basis. This cleansed water temperature is stable and has low daily and weekly variations compared to the influent temperature $[5,57]$. Even in wet weather, the effluent temperature does not have erratic variations like the influent temperature [5].

The potential of WWHR in treated wastewater is higher than sewer pipe wastewater since the downstream water from WWTP can be cooled down to much lower values [5] and effluent water flow is higher. Relatively low variation in water temperature improves the performance of heat pump systems. Since the water is already treated, another advantage is lower bio-fouling and solid matter interference with the heat exchanger, thus improving heat transfer efficiency. However, since the heat consumers are usually not located near WWTP, a major disadvantage of this energy recovery option is that the heat supply must be transported over long distances, thus leading to high heat losses.

Energy consumption in WWTPs is large, for example WWTPs contribution to primary energy consumption in the US is $0.8 \%$ of national energy consumption [58]. Most of the energy consumption is in the form of electricity. On the other hand, WWTPs have a significant amount of energy at their disposal, coming from raw and effluent water and other processes like electricity generation from the incineration of biogas produced from anaerobic digestion and bio-solids [59]. Therefore, WWTPs can be considered as regional energy cells which can deliver energy into local energy supply networks (heat and electricity) [60]. However, with heat supply, the feasibility of such energy cells depends on consumer distance and the treatment capacity of the WWTP. Also, a major constraint for recovered heat usage is that a local district heating network should be present to which recovered heat can be injected. Therefore, on-site consumption can be preferred in such cases to heat buildings in the WWTP precinct.

Regarding the energy potential, heat available in effluent at WWTP is substantial due to high water volumes. Other than water amount, energy potential depends upon the temperature drop of effluent after energy recovery. Based upon different studies in the literature, the temperature drop can be up to $8{ }^{\circ} \mathrm{C}$; however, it depends upon the lower temperature limit allocated by relevant environment protection organizations to protect the ecology of receiving waters. Đurđević et al. [61] presented a theoretical case study to analyze the utilization of WWHR in the city of Rijeka, Croatia. The location considered for the case study had a WWTP in operation with a capacity of 540,000 PE and $3000 \mathrm{~L} / \mathrm{s}$ of effluent water at maximum load. Based upon considered water flow and a temperature drop of $6.5^{\circ} \mathrm{C}, 75 \mathrm{MW}$ of heat recovery potential was shown, which was $72 \%$ of the existing natural gas power heat plant capacity. The study also analyzed the COP of the proposed heat pump, which decreased from 4.7 to 2.87 with an increase in condensation temperature from $60{ }^{\circ} \mathrm{C}$ to $90{ }^{\circ} \mathrm{C}$.

As previously mentioned, the delivery of recovered heat from a WWTP to consumers could be impractical because of the high heat losses; or in some situations, a district heat 
distribution network may not be present. Therefore, in such cases, on-site usage of recovered heat can be more sensible. However, in these cases, only a fraction of available heat in wastewater is used. For example-Chae and Kang [62] performed a study to estimate the energy independence of WWTPs with three different energy resources-photovoltaic panels, small-hydropower and WWHR. Under the considered design conditions for photovoltaic panels, hydropower turbine, and heat pump, $6.5 \%$ of total energy consumption was estimated to be covered by the proposed energy resources. Heat recovery from wastewater had the highest potential among them, at around 3.65\%. The payback period of the heat recovery system considered in the study was estimated to be 6.8 years. Even though the recovered heat supplied all of the heating demand required by the buildings in the WWTP precinct, the heating demand was only limited to $2.2 \%$ of available heat (temperature drop $=3{ }^{\circ} \mathrm{C}$ ) in effluent water. Therefore, much of the available heat in effluent water remained unexploited.

Apart from supplying the space-heating and hot water demand of WWTPs, recovered heat can also be used for low-temperature treatment processes. Pochwala and Kotas [63] presented such a case study. The heat was recovered from raw wastewater and used to heat an on-site building to raise the temperature of a sequential biological reactor (SBR) to the optimum value for the treatment process. The recovered heat supplied $98 \%$ of the heat demand of WWTP.

It is evident that heat recovery from effluent water at WWTPs is an abundant source of energy supply. However, to realize the full potential of this form of energy recovery, a local district heating/cooling network is necessary. Most existing heat recovery practices from WWTP effluent around the world are large scale capacity heat pumps and supply heating/cooling to district heating, and cooling networks [5].

\subsection{Summary of Analyzed Studies}

The studies analyzed in the present paper focusing upon WWHR at different levels are summarized in Table 1 . The table categorizes the analyzed studies based upon energy recovery level, technologies used, approach of the study and analyzed aspects of WWHR.

Table 1. Summary of studies analyzed in the present research.

\begin{tabular}{|c|c|c|c|c|c|c|c|}
\hline Studies & Scale & Technology & Numerical & Experimental & $\begin{array}{c}\text { Energy } \\
\text { Analysis }\end{array}$ & $\begin{array}{l}\text { Economic } \\
\text { Analysis }\end{array}$ & $\begin{array}{l}\text { Emission } \\
\text { Analysis }\end{array}$ \\
\hline$[23,42,45,64]$ & \multirow{24}{*}{$\begin{array}{c}\text { Building level } \\
\text { Component level } \\
\text { Component level } \\
\text { Component level } \\
\text { Component level } \\
\text { Building level } \\
\text { Building level } \\
\text { Building level } \\
\text { Building level } \\
\text { Building level } \\
\text { Building level } \\
\text { Building level } \\
\text { Building level, } \\
\text { Sewer level } \\
\text { Sewer level } \\
\text { Sewer level } \\
\text { Sewer level } \\
\text { Sewer level } \\
\text { WWTP level } \\
\text { WWTP level } \\
\text { WWTP level } \\
\text { WWTP level } \\
\text { (raw water) } \\
\text { WWTP level } \\
\text { WWTP level } \\
\text { (raw, cleansed }\end{array}$} & $\mathrm{HP}^{1}, \mathrm{HE}^{2}, \mathrm{GWS}^{3}$ & $凶$ & $\square$ & $\otimes$ & $\nabla$ & $\nabla$ \\
\hline$[28,65,66]$ & & $\mathrm{HE}$ & $凶$ & $\square$ & $\otimes$ & $\otimes$ & $\square$ \\
\hline [13] & & $\mathrm{HE}$ & $\bigotimes$ & $\otimes$ & $\nabla$ & 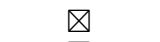 & $\square$ \\
\hline$[66]$ & & $\mathrm{HE}$ & $\otimes$ & $\square$ & $\nabla$ & $\square$ & $\square$ \\
\hline$[17,67]$ & & $\mathrm{HE}$ & $\otimes$ & $\nabla$ & $\nabla$ & $\square$ & $\square$ \\
\hline$[68,69]$ & & $\mathrm{HE}$ & $凶$ & $\square$ & $\otimes$ & $凶$ & $\square$ \\
\hline$[24,25,36,40,70]$ & & HP,HE, GWS & 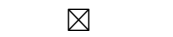 & $\square$ & $\otimes$ & $\square$ & $\square$ \\
\hline$[35,38,71]$ & & HP, HE, GWS & $\square$ & 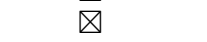 & $\nabla$ & 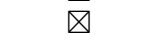 & $\square$ \\
\hline$[44,72]$ & & HE, HP & 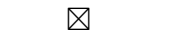 & $\square$ & $\otimes$ & $\otimes$ & $\square$ \\
\hline$[37,73]$ & & HE, HP, GWS & $\square$ & $\bar{\nabla}$ & $\bar{\nabla}$ & $\square$ & $\square$ \\
\hline [74] & & $\mathrm{HE}$ & $\square$ & $\otimes$ & $\otimes$ & $\otimes$ & $\square$ \\
\hline$[75]$ & & $\mathrm{HE}$ & $凶$ & $\square$ & $\otimes$ & $\square$ & $\square$ \\
\hline [50] & & HE, HP & $\otimes$ & $\square$ & $\otimes$ & $\square$ & $\square$ \\
\hline [52-54] & & HW, HP & $凶$ & $\square$ & $\otimes$ & $\otimes$ & $\square$ \\
\hline [49] & & HE, HP & $凶$ & $\square$ & 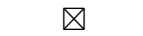 & $\square$ & $\square$ \\
\hline [47] & & HE, GWS, HP & $\square$ & 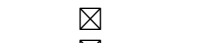 & 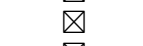 & 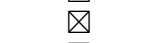 & $\square$ \\
\hline [48] & & HE, GWS, HP & $\square$ & $凶$ & 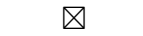 & $\otimes$ & $\square$ \\
\hline$[61,76]$ & & $\mathrm{HE}, \mathrm{HP}$ & $\bar{\nabla}$ & $\square$ & $\otimes$ & $\square$ & $\square$ \\
\hline [77] & & HE, HP & $\square$ & $凶$ & $\otimes$ & $\square$ & $\square$ \\
\hline [62] & & HP & 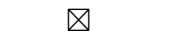 & $\square$ & $\bar{\nabla}$ & $\bar{\nabla}$ & $\bar{\nabla}$ \\
\hline [78] & & HE, HP & $\square$ & $凶$ & $\otimes$ & $\square$ & $\square$ \\
\hline [62] & & $\mathrm{HP}$ & $\otimes$ & $\square$ & $\otimes$ & $\square$ & $\square$ \\
\hline & & & & & & & \\
\hline [63] & & $\mathrm{HP}, \mathrm{HE}$ & $凶$ & $\square$ & 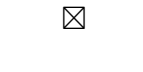 & $\square$ & $\square$ \\
\hline
\end{tabular}

${ }^{1}$ Heat pump,${ }^{2}$ Heat exchanger, ${ }^{3}$ Grey water storage. 
It can be seen in Table 1 that only a few studies have considered the environmental impacts (emission analysis) of WWHR. Many studies do not account for the economic cost analysis of proposed WWHR systems. The majority of the studies are numerical based studies analyzing the potential of energy savings based on wastewater flow and temperature measurements. Evidently, at the component level, only heat exchangers are used as the heat recovery technology due to the economic in-feasibility of heat pumps in this case. Further, Table 2 summarizes different WWHR technologies at various level of heat recovery and present their main characteristics.

Table 2. Summary for wastewater heat recovery technologies.

\begin{tabular}{|c|c|c|}
\hline Technology & Scale & Characteristics \\
\hline $\begin{array}{l}\text { Vertical wastewater } \\
\text { heat exchanger }\end{array}$ & Component & $\begin{array}{l}\text { - } \quad \text { Can be used for preheating shower water } \\
\text { - } \quad \text { Higher space requirements } \\
\text { Higher efficiency due to the higher contact surface area }\end{array}$ \\
\hline $\begin{array}{l}\text { Horizontal wastewater } \\
\text { heat exchanger }\end{array}$ & Component & $\begin{array}{l}\text { - } \quad \text { Suitable for preheating shower water } \\
\text { - } \quad \text { Low space requirements } \\
\text { Less efficient due to the lower contact surface area }\end{array}$ \\
\hline $\begin{array}{l}\text { Heat exchanger with } \\
\text { wastewater storage tank }\end{array}$ & Building & $\begin{array}{l}\text { - Hot water is stored in the storage tank } \\
\text { - } \quad \text { Higher cost of the device due to the additional storage tank } \\
\text { - } \quad \text { ore feasible with a heat pump }\end{array}$ \\
\hline Heat pump with heat exchanger & Building & $\begin{array}{ll}-\quad \text { Higher energy recovery } \\
-\quad \text { Less economic feasibility for individual dwellings }\end{array}$ \\
\hline $\begin{array}{l}\text { Integrated heat exchanger in } \\
\text { sewer pipes with heat pumps }\end{array}$ & Sewer & $\begin{array}{l}\text { - Heat exchanger in the sewer pipe bed } \\
\text { - Need to meet technical specifications based upon sewer } \\
\text { pipe parameters } \\
\text { - No additional space requirements } \\
\text { - More prone to fouling and demand regular maintenance }\end{array}$ \\
\hline $\begin{array}{l}\text { External heat exchanger with } \\
\text { heat pumps }\end{array}$ & Sewer & $\begin{array}{l}\text { - } \quad \text { Sewage is pumped out of the sewer pipe } \\
\text { - } \quad \text { Less prone to fouling due to pre-screening of wastwater } \\
\text { - } \quad \text { Addependent of the sewer pipe and easy maintenance } \\
\quad \text { space requirements }\end{array}$ \\
\hline
\end{tabular}

\section{Wastewater Temperature and Flow Characteristics}

Wastewater flow and temperature characteristics are crucial for determining WWHR potential. Higher values of flow and temperature lead to higher heat recovery. The temperature of wastewater is highest at the component level since heat loss to the environment is low. As wastewater streams from component to building drain and sewer, heat is lost to the environment, and temperature decreases. For wastewater flow, the amount of wastewater produced is also relatively low and highly fluctuating at the component level and building level. At the sewer pipe level and WWTP level, wastewater flow rates are higher and more stable throughout the year.

\subsection{Building Level}

Wastewater flow and temperature characteristics differ for different types of buildings, such as buildings containing public showers (e.g., leisure centres), residential buildings, restaurants/kitchens and so forth. For residential settings, measurements and estimations from different studies are available for wastewater flow and temperature values. Meinzinger and Oldenburg [79] reviewed more than 130 studies spanning over 20 countries and reported that wastewater volume in a household can range from 69-150 L per day (d) per capita (c) with a median value of $110 \mathrm{~L} / \mathrm{c} . \mathrm{d}$. Regarding the domestic wastewater temperature, it can vary from $16-38{ }^{\circ} \mathrm{C}$ as reported by Heinz et al. [80]. Alnahal and Spremberg [72] conducted a study in which they measured the wastewater temperature for a student hostel in Berlin for one month period. The daily average wastewater temperature varied from $11^{\circ} \mathrm{C}$ to $20^{\circ} \mathrm{C}$ with an average of $15^{\circ} \mathrm{C}$. 
Wastewater temperature and flow rate are closely related to end-use water temperature and flow rate. If information about end-use is available, wastewater flow and temperature can be estimated based upon that. Stochastic models, such as SIMDEUM ${ }^{\circledR}$ [81], and the WaterHub framework [82], have been successfully applied to predict wastewater flow and temperature from households and buildings [82,83]. The Building America Research Benchmark Definition [84] provides a general model for end-use hot water consumption, described in Table $3 . \mathrm{N}_{\mathrm{br}}$ represents the number of bedrooms in the dwelling. Figure 6 depicts the hourly hot water use for each end-use as a fraction of total end-use [24].

Table 3. Domestic hot water consumption by end-use.

\begin{tabular}{lll}
\hline End-Use & End-Use Water Temperature $\left({ }^{\circ} \mathbf{C}\right)$ & Water Usage (L/d) \\
\hline Clothes washer & 49.0 & $28.4+9.46 \mathrm{~N}_{\mathrm{br}}$ \\
Dishwasher & 49.0 & $9.46+3.15 \mathrm{~N}_{\mathrm{br}}$ \\
Shower & 40.6 & $53+17.67 \mathrm{~N}_{\mathrm{br}}$ \\
Bath & 40.6 & $13.25+4.43 \mathrm{~N}_{\mathrm{br}}$ \\
Sinks & 40.6 & $47.32+15.75 \mathrm{~N} \mathrm{br}^{\mathrm{b}}$ \\
\hline
\end{tabular}

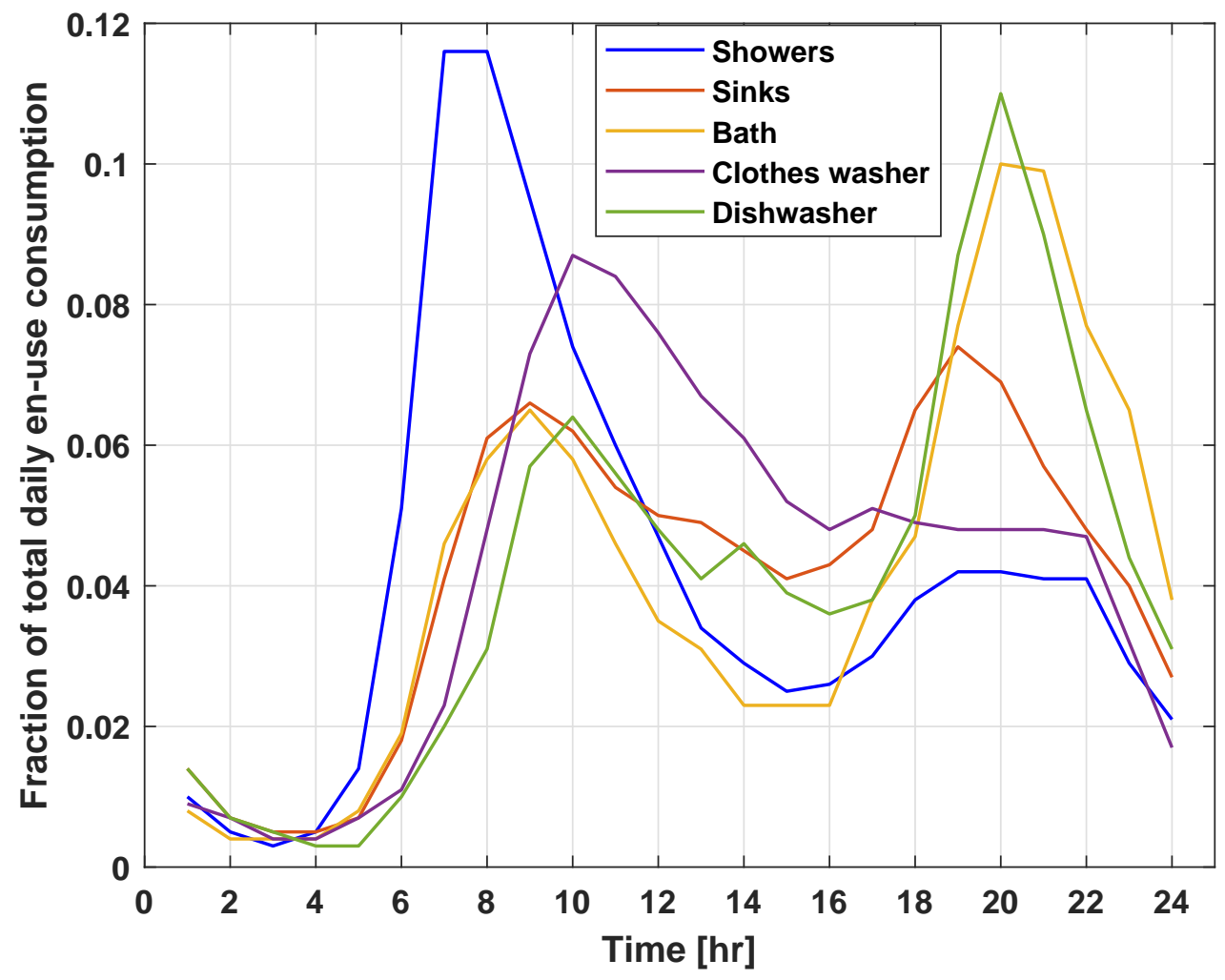

Figure 6. Typical hot water usage profile [24].

Based upon Table 3 and Figure 6 , the hourly hot water flow rate $\left(L_{\text {hot }}\right)$ for a residential dwelling can be calculated as [24]

$$
L_{\text {hot }}=\sum L_{\text {end }- \text { use }, i} \times P_{\text {end }- \text { use }, i} \times \frac{T_{\text {end }- \text { use }, i}-T_{\text {mains }}}{T_{\text {hot }}-T_{\text {mains }}},
$$

where $L_{\text {end-use, } i}$ and $T_{\text {end-use }}$ are water consumption and temperature for $i$ th end-use. $T_{\text {hot }}$ is the hot water supply temperature and $T_{\text {mains }}$ is the cold water supply temperature which depends upon ambient temperature $T_{\mathrm{amb}}$.

The temperature of the drain water $T_{\text {grey }}\left({ }^{\circ} \mathrm{C}\right)$ can be estimated as [24]

$$
T_{\text {grey }}=T_{\text {mains }}+\frac{\left(1-0.01 \eta_{V}\right) L_{\text {hot,grey }}}{L_{\text {grey }}}\left[\left(1-0.01 \eta_{T}\right) T_{\text {hot }}-T_{\text {mains }}\right] \text {, }
$$


where $\eta_{T}$ and $\eta_{V}$ are the loss coefficient of hot water flow rate (\%) and (\%) temperature respectively. $L_{\text {grey }}$ and $L_{\text {hot,grey }}$ are the flow rate of grey water and hot water which turns into grey water respectively.

Another way to model wastewater temperature is based upon measurements and correlation analysis. For example, Wong et al. [17] in their experimental study measured the incoming cold water supply $\left(T_{0}\right)$, shower head temperature $\left(T_{2}\right)$, shower drain water $\left(T_{3}\right)$ and ambient temperature $\left(T_{a}\right)$ for different months of the year; and established a numerical model using correlation analysis to represent cold water supply temperature and a temperature drop of shower water from head to the drain in terms of outdoor air temperature.

$$
\begin{aligned}
& T_{0}=10.4 T_{a}^{0.29} ; \quad 13^{\circ} \mathrm{C} \leq T_{a} \leq 28^{\circ} \mathrm{C} \\
& T_{2}-T_{3}=3.6 \times 10^{-10} T_{2}^{6.673} T_{a}^{-0.530} .
\end{aligned}
$$

\subsection{Sewer Pipe Scale}

In sewer pipe systems, wastewater flow and temperature depend upon upstream wastewater discharge into sewers from different buildings. It also depends on ambient air and ground temperatures and the water volume already flowing in the sewer, sewer size, among other factors. Cipolla and Maglionico [49] measured wastewater flow in a sewer system in Bologna, Italy, at five different locations (conduits). The wastewater flow varied from $10 \mathrm{~L} / \mathrm{s}$ to $1700 \mathrm{~L} / \mathrm{s}$ depending upon the measurement location with a differing number of inhabitants in the catchment. Kretschmer et al. [85] analyzed spatial and temporal variation in the wastewater flow in a sewer system in a valley in Austria with flow variation of around 5-60 L/s depending upon the month and measurement location.

In the case of wastewater temperature, Table 4 shows the sewer pipe wastewater temperature range for various locations measured in different studies. These studies help to provide the range of wastewater temperature in sewer systems.

Table 4. Wastewater temperature measurement found in literature.

\begin{tabular}{llll}
\hline Study & Location & Period & Temperature Range $\left({ }^{\circ} \mathbf{C}\right)$ \\
\hline Cipolla and Maglionico [49] & Bologna, Italy & Oct 2005-Mar 2006 & $10-22$ \\
Schmid [5] & Zurich, Switzerland & Jan 2005- Dec 2006 & $10-25$ \\
Schilperoort and Clemens [86] & Ede, Netherlands, & 15-23 Dec 2008 & $12-14$ \\
Pramminger et al. [54] & Melbourne, Australia & Jan 2012-Jun 2012 & $13.1-21.1$ \\
Wu et al. [87] & Harbin, China & - & $12-20$ \\
Abdel-Aal et al. [88] & Antwerp, Belgium & Feb 2012-Jan 2013 & $7-22$ \\
Pramminger et al. [54] & Melbourne, Australia & Jan 2012-Jun 2012 & $13.1-21.1$ \\
\hline
\end{tabular}

In sewer pipes, spatio-temporal analysis and modelling of thermal dynamics of wastewater are essential. This modelling can be applied to assess different potential sites for WWHR installation. Another application of such a model can be to understand the effect of heat extraction from wastewater on the downstream wastewater temperature. For example, it is sometimes required for wastewater to have a specific minimum temperature before it enters the WWTP, $10{ }^{\circ} \mathrm{C}$ for Switzerland. A lower temperature of wastewater than the minimum requirement can influence the process of nitrification in WWTPs. Countermeasures need to be implemented to handle this effect at the planning stage. Lower temperatures in sewer pipes may also influence the formation of fatbergs, and thus modelling the impact of heat extract on this aspect of sewer operation is crucial.

The following models exist in literature that model thermal dynamics of wastewater in sewer systems. 


\subsubsection{Alligation Alternate}

Alligation alternate is a relatively simple method for modelling wastewater temperature dynamics $[89,90]$. In this method, the temperature of two mixing wastewater fluids (Figure 7) with flow rate and temperature of $Q_{A}, T_{A}$ and $Q_{B}, T_{B}$ is estimated as follows:

$$
\begin{aligned}
& Q_{C} \times T_{C}=Q_{A} \times T_{A}+Q_{B} \times T_{B} \\
& Q_{C}=Q_{A}+Q_{B} .
\end{aligned}
$$

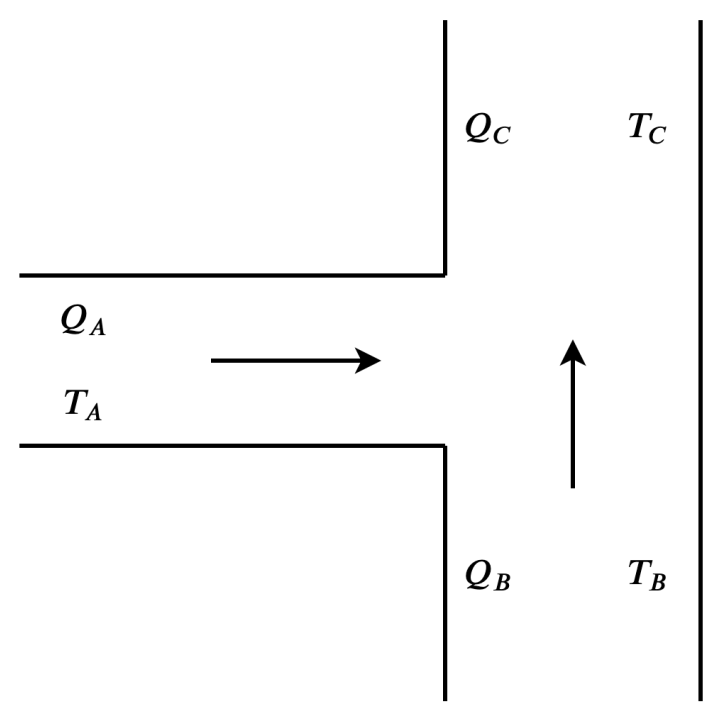

Figure 7. Schematic of alligation alternate method.

In the context of modelling the wastewater thermal dynamics, the two flows may not be separate flows mixing at one point, rather two points within the sewer pipe system; for example-one point is the point of heat extraction, and the other point is the inlet of a WWTP. The method does not require measurements of many parameters, only wastewater temperature and discharge. However, this method does not consider the heat exchange processes with in-sewer air, surrounding soil and sewer pipe walls, which is the main reason for the model's low accuracy. Kretschmer et al. [85] used this approach to analyze wastewater temperature evolution and WWHR potential in a sewer system (Austria) considering the impact on inflow temperature WWTPs.

\subsubsection{TEMPEST}

TEMPEST is a model developed by Dürrenmatt and Wanner [91], which estimates the dynamics and longitudinal spatial profiles of wastewater in sewer systems. It is based upon heat and mass balance in sewer systems [92]. TEMPEST models a sewer system as two basic elements conduits and nodes. Conduits are modelled by 1-D balance equations. Nodes are introduced to represent discontinuities in the sewer line due to lateral inflows, changes in pipe geometry, material properties or surrounding soil properties; and are modelled using continuity equations.

The case study by Dürrenmatt and Wanner [93] demonstrated using TEMPEST that the heat transfer between wastewater and the surrounding soil was the most significant heat transfer process.

The study by Ali and Gillich [94] used TEMPEST to estimate heat recovery potential at a sewer site in London with lateral inflow mixing. Elías-Maxil et al. [95] presented a simplified parsimonious model based upon TEMPEST, considering only the heat transfer from water to the surroundings. A case study based upon the previous model was presented by Hoffman et al. in [96]. The study concluded that in un-steady conditions, the model was more than twice as accurate as TEMPEST, which was due to consideration 
of the hydraulic influence of maintenance holes, other empty space and pump regime in modelling of wastewater flow.

Sitzenfrei et al. [97] used TEMPEST to analyze the interaction of decentralized (building level) and centralized (sewer pipe) WWHR systems. The study concluded that the performance of centralized heat recovery systems decrease up to $40 \%$ when all the dwellings are equipped with decentralized WWHR systems.

\subsubsection{Abdel Aal et al. Model}

Abdel Aal et al. [98] proposed a simplified model for wastewater temperature dynamics realizing that many input parameters in TEMPEST have insignificant effects on wastewater temperature evolution. The model included an energy balance along the pipe and estimation of heat transfer coefficients and assumed that the temperature variation of wastewater is caused by heat losses to in-sewer air and the surrounding soil. Using this model, Abdel Aal et al. showed that [98], the in-sewer air temperature has the most influence on wastewater temperature dynamics followed by the surrounding soil temperature, contrary to the TEMPEST model [98]. The sewer pipe was modeled as discrete cross-sections of length $\nabla L$.

The temperature evolution along the sewer pipe is given in Equation (6), where the parameters involved in the model are described in Table 5

$$
T_{j+1}=T_{j}-\left(\frac{\frac{1}{R_{w a}} \times\left(T_{w}-T_{a}\right)+\frac{1}{R_{w s}} \times\left(T_{w}-T_{s}\right)}{\dot{M} \times c_{p}}\right),
$$

where

$$
\begin{aligned}
R_{w a} & =\frac{1}{h_{w a} \times b \times n \times \nabla L} \\
R_{w s} & =\frac{w t}{k_{p} \times \text { wet. } p \times n \times \nabla L}+\frac{d_{s}}{k_{s} \times \text { wet. } p \times n \times \nabla L} .
\end{aligned}
$$

\begin{tabular}{|c|c|c|}
\hline Parameter & Description & Unit \\
\hline$w t$ & Pipe wall thickness & $\mathrm{m}$ \\
\hline$d_{s}$ & Soil-depth to which heat is transferred & $\mathrm{m}$ \\
\hline$R_{w a}$ & $\begin{array}{l}\text { Overall thermal resistivity between } \\
\text { wastewater and in-sewer air }\end{array}$ & $\mathrm{m}^{2} \cdot \mathrm{K} / \mathrm{W}$ \\
\hline$R_{w s}$ & $\begin{array}{l}\text { Overall thermal resistivity between } \\
\text { wastewater and surrounding soil }\end{array}$ & $\mathrm{m}^{2} \cdot \mathrm{K} / \mathrm{W}$ \\
\hline$T_{w}$ & Wastewater temperature & $\mathrm{K}$ \\
\hline$T_{a}$ & In-sewer air temperature & $\mathrm{K}$ \\
\hline$T_{S}$ & Soil temperature & $\mathrm{K}$ \\
\hline$T_{j}$ & Wastewater Temperature at node $\mathrm{j}$ & K \\
\hline$M$ & Mass flow rate of the wastewater & $\mathrm{g} / \mathrm{s}$ \\
\hline & Specific heat capacity of wastewater & $\mathrm{J} /(\mathrm{g} . \mathrm{K})$ \\
\hline wet.p & Wetted perimeter & $\mathrm{m}$ \\
\hline$b$ & Wastewater free surface width & $\mathrm{m}$ \\
\hline$k_{p}$ & Thermal conductivity of sewer pipe & $\mathrm{W} /(\mathrm{m} . \mathrm{K})$ \\
\hline$k_{s}^{r}$ & Thermal conductivity of surrounding soil & $\mathrm{W} /(\mathrm{m} \cdot \mathrm{K})$ \\
\hline$h_{w a}$ & $\begin{array}{l}\text { Heat transfer coefficient between wastewater } \\
\text { and in-sewer air }\end{array}$ & $\mathrm{W} /\left(\mathrm{m}^{2} \cdot \mathrm{K}\right)$ \\
\hline$n$ & Increment number & \\
\hline$\nabla L$ & Increment length or mesh size & $\mathrm{m}$ \\
\hline
\end{tabular}

Table 5. Parameters description of Abdel aal et al. model.

Equation (6) is used sequentially to find the wastewater temperature at nodes $\left(T_{j+1}, T_{j+2} \ldots T_{j+n}\right)$ along the sewer line starting from the upstream temperature $T_{j}$.

Saagi et al. [99] used this model for analyzing the sewer system in two Swedish cities (Linköping, Malmö) with maximum prediction error ranging from $0.7-0.9^{\circ} \mathrm{C}$. 
Extending on the previous model, Abdel aal et al. [100] published a recent study to analyze the impact of the in-sewer air velocity profile, close to the wastewater surface, on the heat transfer processes and proposed an improved method to estimate a new heat transfer coefficient by employing a dimensionless calibrating factor.

\subsubsection{Other Measurements Based Approaches}

In contrast to intricate heat transfer models, measurement based approach relies upon historical measurements and mathematical models to capture the relationship between relevant input and output parameters. Various measurements such as wastewater temperature, soil temperature, ambient air temperature, wastewater discharge and so forth, have been taken over a certain period of time; and relationship were established between these variables through mathematical tools like correlation analysis. An example of such an approach can be seen in the study by Escalas-Cañellas et al. [101]. The authors used a time series modelling method, where future wastewater temperature is predicted based upon historical temperature, mean daily ambient temperature and rainfall. A modelling error of $0.5^{\circ} \mathrm{C}$ (RMSE) between predicted and the measured temperature was observed.

Abdel Aal et al. [102] used another approach, where sewer wastewater temperature was modelled using an Abductory Inductive Mechanism (AIM), a supervised learning technique. Two parameters, upstream wastewater temperature and downstream in-sewer air temperature, were used as inputs. The study carried out a comparison with the model developed by Abdel et al. [98] and showed that the proposed AIM estimates the wastewater temperature with higher accuracy.

In a recent study, Golzar et al. [103] used an artificial neural network to forecast the influent wastewater temperature of a WWTP. The model considered ambient temperature, building effluent temperature and flowrate, stormwater flowrate, infiltration flowrate, the hour of the day, and the day of the year as the input parameters.

In conclusion, while TEMPEST uses a comprehensive modelling approach taking various heat transfer processes, other more simplified models can capture the temperature dynamics with acceptable accuracy. More experimental studies could help to further validate these approaches.

\section{Impacts of WWHR}

\subsection{Life Cycle Environmental Assessment}

It is evident that WWHR leads to a reduction in GHG emissions by lowering primary energy usage. However, to analyze the overall sustainability of WWHR, it is vital to consider the full life-cycle environmental assessment (LCA) of the technology. Typically, researchers emphasize upon energy savings of WWHR; some have examined the GHG emission savings also. However, the LCA of the WWHR technologies has not gained considerable attention from the research community so far, and the literature associated is limited.

Ip et al. [104] presented a case study focusing upon LCA of shower water heat recovery in a sports-facility. The study's goal was to perform an LCA of wastewater heat exchangers (WWHXs) installed in the facility compared against PVC-u pipe with no heat recovery. The results showed that the lifetime GHG emission $\left(\mathrm{kg} \mathrm{CO}_{2}-\mathrm{e}\right)$ of WWHX was five times more than the PVC-u pipe. However, the reduction in GHG emission during the operational stage of WWHX indicated an emission payback period of 0.55-10.02 years, depending upon the usage.

A study by Schestak et al. [105] analyzed the sustainability of WWHR in a commercial kitchen in North Wales, UK. The study employed LCA to determine the impact of heat recovery with a concentric double-walled pipe heat exchanger and associated pipes and fittings. The study further explored the possibilities of using recycled copper and polypropylene-graphite instead of copper. The results demonstrated that GHG emissions of the heat exchanger ranged from 16 to $87 \mathrm{kgCO}_{2} \mathrm{e}$. The heat exchanger with the com- 
bination of recycled copper (35\%) and polymer material was concluded to be the most environmentally friendly option that is currently available in the market.

\subsection{Impact on Water Treatment Process}

In wastewater treatment processes, temperature plays an important role. The rate of biological and chemical reactions in some elements of wastewater treatment strongly depend upon temperature [106]. Many existing studies in literature solely focus on modelling temperature in activated sludge basins [107-109] reflecting its importance. Recovering heat from wastewater in sewer systems may lead to a reduction in influent temperature at WWTPs. This is particularly important if heat recovery upstream is near the WWTP since, for heat recovery at a long-distance upstream, the sewage temperature may regain heat again from the surrounding air and soil. The decrement $\Delta T$ in wastewater temperature can be calculated as follows

$$
\Delta T=\frac{Q}{\rho c_{p} \dot{V}^{\prime}}
$$

where $Q$ is the amount recovered heat per unit time, $\dot{V}, \rho$ and $c_{p}$ are the volumetric flow rate, density and the specific heat capacity of wastewater. The reduction in the temperature of influent wastewater can negatively impact the nitrification/denitrification capacity of WWTP.

Wanner et al. [110] specifically investigated the effect of heat recovery on nitrification and nitrogen removal for a WWTP in Zurich, Switzerland. The influent and effluent temperatures were measured during both dry and wet conditions. Wanner et al. [110] argued that a temporary reduction (over a couple of hours) in the temperature of wastewater did not affect the nitrification capacity due to long hydraulic retention time in activated sludge tanks and the secondary clarifiers. The authors also concluded that a long-lasting reduction of $1{ }^{\circ} \mathrm{C}$ in wastewater temperature causes a $10 \%$ reduction in nitrifying bacteria. To deal with this change, $10 \%$ of aerobic sludge retention would have to be increased.

Lotti et al. [111] reported the effects of temperature on growth of anaerobic-ammoniumoxidation (Anammox) bacteria activity. The study concluded that the anammox activity could not be effectively described with the Arrhenius equation when exploring the lowtemperature range $\left(<15^{\circ} \mathrm{C}\right)$.

Brehar et al. [112] presented a case study of a municipal WWTP in Romania to investigate the effect of influent temperature on the wastewater treatment process. The study observed increased microbial activity, escalated nitrification and denitrification, and decreased nitrate, nitrite and ammonia concentrations at higher influent temperatures. Overall, the study concluded that in terms of nitrogen removal from wastewater, a decrease in influent temperature could negatively impact the performance of WWTP.

Abdel et al. [113] presented a laboratory-scale study to investigate the impact of sewer heat recovery on in-sewer processes such as deposition of Fats, Oils and Greases (FOGs) and hydrogen-sulphide $\left(\mathrm{H}_{2} \mathrm{~S}\right)$ emissions. The study concluded no unique temperature dependency on the rate of FOG deposition in the laboratory set-up used. Regarding the $\mathrm{H}_{2} \mathrm{~S}$, a $40 \%$ reduction in $\mathrm{H}_{2} \mathrm{~S}$ concentration was observed for wastewater at $5{ }^{\circ} \mathrm{C}$ compared to $20^{\circ} \mathrm{C}$. In conclusion, the reduced wastewater temperatures due to WWHR can significantly reduce $\mathrm{H}_{2} \mathrm{~S}$ formation. The effect on FOG deposition demands further research.

In general, it is clear from the literature that temperature change can result in impacts on the wastewater treatment process. However, it is unclear whether WWHR at the component or building levels would significantly impact influent temperatures. Further research is required in this regard.

\subsection{Impact on the Receiving Water Ecology}

The variation in the wastewater discharge temperature from WWTPs can have considerable consequences on receiving water bodies' ecology. The reduction in treated wastewater temperature is positive for the biological community of the receiving water [114]. In the case of cooling, the heat input to the wastewater or increase in water body temperature 
can intensify biological processes leading to an accelerated oxygen depletion, which can negatively impact the water ecology [114].

\section{Legal Frameworks}

Some governments have begun to develop legal guidelines to regulate thermal energy recovery from wastewater. Notable examples include guidelines from the Canton of Zurich, Switzerland, and the German Association of Water, Wastewater and Waste [41,90]. The Swiss guidelines clarify that the ownership of the thermal resource lies with sewer and WWTP operators. Hence, any exploitation of the resource must be approved by these infrastructure operators. Further, if heat recovery occurs at the outlet of a WWTP, additional approval is required from appropriate regulatory authorities. This ensures that the size of any water bodies receiving wastewater discharge is reasonable and have no excessive thermal loading due to any heat recovery. For in-sewer heat recovery, both guidelines stress the importance of maintaining a minimum wastewater temperature to ensure nitrogen removal at WWTPs. The German guidelines also require that the hydraulic function of sewers is sustained to ensure no excess solids accumulation occurs when heat exchangers are installed. On the other hand, many guidelines set a criteria for maximum temperature for wastewater disposal also [115]. If the wastewater is released at a high temperature, which is the case for many utility operations and industries, WWHR can bring potential benefit by recovering energy as well as maintaining the receiving water conditions.

In terms of the ownership of larger heat recovery schemes, the development of an energy utility by the City of Vancouver to distribute heat recovered from wastewater provides a model on how this can be achieved [116]. Thus far, the work undertaken in regulating the recovery and distribution of heat recovered from wastewater provides a solid foundation for its broader implementation.

\section{Concluding Remarks and Future Directions}

Wastewater contains a considerable amount of thermal energy, which can be recovered at different points in the water cycle and utilized to reduce heating demand. Thermal energy is extracted using either heat exchangers or a combination of heat exchangers and heat pumps. Some key points that can be concluded are

- Heat recovery from shower water using a heat exchanger can be an efficient and economically viable option. Vertical heat exchangers have large space requirements, and retrofitting of WWHR system can increase the investment costs.

- At the domestic building level, due to low quantities of wastewater flow and high economic costs, heat pumps are not a viable option for heat recovery at the current prices of alternative heating sources. It is feasible to use a wastewater source heat pump at properties with higher volumes of wastewater discharge, such as public showers, gymnasium, sports centre, commercial kitchen, apartment complexes, and so forth.

- Further research should be carried out with a focus on policy and decision making to improve the economic competitiveness of WWHR systems at the domestic building level.

- At the sewer pipe level, wastewater flow is in abundant quantity. The temperature varies from 10 to $25^{\circ} \mathrm{C}$ throughout the year with low daily variation, which makes sewer water an ideal low-grade heat source for heat pumps. The main disadvantage, in this case, is the fouling of heat exchangers, which can reduce the efficiency of the heat recovery system, thus requiring regular maintenance.

- Economic savings and payback period for WWHR at sewer pipe level can depend upon many factors, including current electricity prices, more prolonged period usage of WWHR system and the cost of traditional fuel sources.

- Research studies considering the energy, economic and environmental aspects of WWHR collectively are still limited in the literature. 
- The surrounding soil of a sewer pipe and in-sewer air are the two major sources of heat loss for sewer wastewater.

- Downstream of WWTPs, the wastewater temperature is relatively stable and can be cooled down to much lower levels. However, there can be higher heat transmission losses in this case due to the often distant location of WWTPs from the consumers.

- Along with the positive impacts such as reduction of primary energy usage and GHG emissions, WWHR from sewer wastewater could negatively impact the nitrification capacity of WWTP, leading to higher ammonium concentration in the effluent water of WWTP. However, the upstream impact of WWHR on the downstream treatment require further investigation to fully quantify what this potential effect might be.

In addition to the above key findings of the present work, some future suggestions and recommendations can be summarized as follows:

- In order to encourage heat recovery at the component and the building level, various countries can introduce WWHR in their respective building codes and guidelines aimed at improving the energy efficiency of existing and new buildings.

- At present, the conventional technologies are prevalent over such sustainable alternatives due to the low prices of fuel sources. More studies with direct attention to the economic analysis of small and large scale WWHR should be performed to clearly highlight the advantage of WWHR over conventional technologies in the future with the rising cost of traditional fuel sources.

- The non-residential buildings that generate a large amount of wastewater, such as launderette, hotels, and restaurants, food processing industry hold significant potential for WWHR. More research should be dedicated in this direction.

- The impacts of separating wastewater at the source in residential buildings on WWHR can be considered in a future study expanding on previous work from Ni et al. [24]. As discussed in Section 5.1, heat in residential wastewater is predominantly embedded in the greywater component from bathrooms, washing machines, and kitchens. Separating this wastewater at the source in a building could impact the feasibility of WWHR by concentrating the heat available alongside the benefits of simpler treatment of the relatively clean greywater for potential reuse.

- The decentralization of wastewater treatment can be a method to enhance local water recycling, reduce reliance on extensive sewer networks, and reduce the intensity of environmental impacts from large, centralized WWTPs. The interactions of wastewater decentralization and WWHR could be an interesting concept to explore with lower wastewater flows available in small decentralized WWTPs but at potentially higher temperatures due to reduced distances in sewers.

- Another interesting idea would be to explore the integration of WWHR into district heating as a decentralized heating source.

Overall, wastewater is an important source of clean thermal energy with significant potential to improve the energy infrastructure's efficiency and reduce GHG emissions. It should be given more attention from the research community, policymakers and other stakeholder committed to achieving climate neutrality.

Author Contributions: Conceptualization, H.N. and A.M.; methodology, H.N. and A.M.; writingoriginal draft preparation, H.N.; writing - review and editing, H.N., J.S., M.K.M. and A.M.; supervision, A.M.; funding acquisition, A.M. All authors have read and agreed to the published version of the manuscript.

Funding: The present research has been supported by the ERDF Interreg Ireland-Wales Programme 2014-2020, through the Dîr Uisce project.

Institutional Review Board Statement: Not applicable.

Informed Consent Statement: Not applicable.

Data Availability Statement: Not applicable. 
Acknowledgments: The authors acknowledge the funding support from the European Regional Development Fund under Ireland-Wales Co-operation Programme 2014-2020.

Conflicts of Interest: The authors declare no conflict of interest.

\section{References}

1. European Comission. Statistical Pocketbook 2019; Technical Report; Publications Office of the European Union: Luxembourg, 2019. Available online: https://op.europa.eu/en/publication-detail/-/publication/e0544b72-db53-11e9-9c4e-01aa75ed71a1/lang uage-en (accessed on 20 September 2020).

2. Regulation (EU) 2018/1999 of the European Parliament and of the Council of 11 December 2018 on the Governance of the Energy Union and Climate Action. Off. J. Eur. Union 2018, 61, 1-77.

3. Directive (EU) $2018 / 2001$ of the European Parliament and of the Council of 11 December 2018 on the promotion of the use of energy from renewable sources. Off. J. Eur. Union 2018, 5, 82-209.

4. Sustainable Europe Investment Plan European Green Deal Investment Plan; Technical Report; European Commision: Brussels, Belgium, 2020. Available online: https://eur-lex.europa.eu/legal-content/EN/TXT/?uri=CELEX\%3A52020DC0021 (accessed on 20 September 2020).

5. Schmid, F. Sewage water: Interesting heat source for heat pumps and chillers. In Proceedings of the 9th International IEA Heat Pump Conference, Zürich, Switzerland, 20-22 May 2008; pp. 1-12.

6. Mueller, E. Heizen und Kühlen mit Abwasser; Institut Energie in Infrastrukturanlagen: Winterthur, Switzerland, 2009. Available online: https:/ / um.baden-wuerttemberg.de/fileadmin/redaktion/m-um/intern/Dateien/Dokumente/5_Energie/Energieef fizienz/Abwasserwaermenutzung/Leitfaden_Ratgeber/Ratgeber_Heizen_und_Kuehlen.pdf (accessed on 24 September 2020).

7. Hepbasli, A.; Biyik, E.; Ekren, O.; Gunerhan, H.; Araz, M. A key review of wastewater source heat pump (WWSHP) systems. Energy Convers. Manag. 2014, 88, 700-722. [CrossRef]

8. Shen, C.; Lei, Z.; Wang, Y.; Zhang, C.; Yao, Y. A review on the current research and application of wastewater source heat pumps in China. Therm. Sci. Eng. Prog. 2018, 6, 140-156. [CrossRef]

9. Culha, O.; Gunerhan, H.; Biyik, E.; Ekren, O.; Hepbasli, A. Heat exchanger applications in wastewater source heat pumps for buildings: A key review. Energy Build. 2015, 104, 215-232. [CrossRef]

10. Tilley, E. Compendium of Sanitation Systems and Technologies; Eawag: Dübendorf, Switzerland, 2014.

11. Yao, R.; Steemers, K. A method of formulating energy load profile for domestic buildings in the UK. Energy Build. 2005, 37, 663-671. [CrossRef]

12. Grassi, W. Heat Pumps: Fundamentals and Applications; Springer: Cham, Switzerland, 2017. [CrossRef]

13. Zaloum, C.; Gusdorf, J.; Parekh, A. Performance Evaluation of Drain Water Heat Recovery Technology at the Canadian Centre for Housing Technology; Sustainable Buildings and Communities, National Resources Canada: Ottawa, ON, Canada, 2007.

14. Zaloum, C.; Gusdorf, J.; Parekh, A. Drainwater Heat Recovery Performance Testing at Canadian Centre for Housing Technology; Technical Series, CCHT, 07-116; Canada Mortgage and Housing Corporation: Ottawa, ON, Canada, 2007.

15. Frankowski, C. Drain Water Heat Recovery: A Review of Performance, Economics, Practical Issues and Applications. Ph.D. Thesis, University of British Columbia, Vancouver, BC, Canada, 2013. [CrossRef]

16. Shields, K. Drain Water Heat Recovery. Master's Thesis, Trinity College Dublin, University of Dublin, Dublin, Ireland, 2011.

17. Wong, L.; Mui, K.; Guan, Y. Shower water heat recovery in high-rise residential buildings of Hong Kong. Appl. Energy 2010, 87, 703-709. [CrossRef]

18. Tomislon, J. Heat Recovery from Wastewater Using a Gravity-Film Heat Exchanger. In Federal Energy Management Program; Department of Energy: Washington, DC, USA, 2005. Available online: https://www.fpl.fs.fed.us/documnts/informationalkits/i nfokit_0003_DrainwaterFact\%20Sheet.pdf (accessed on 26 September 2020)

19. Pochwat, K.; Kordana, S.; Starzec, M.; Słyś, D. Comparison of two-prototype near-horizontal Drain Water Heat Recovery units on the basis of effectiveness. Energy 2019, 173, 1196-1207. [CrossRef]

20. McNabola, A.; Shields, K. Efficient drain water heat recovery in horizontal domestic shower drains. Energy Build. 2013, 59, 44-49. [CrossRef]

21. Kimmels, A. Shower Heat Recovery: Overview of Commercially Available DWHR Systems; Meander Heat Recovery: Selpenden, Norway, 2011. Available online: http://www.meanderhr.com/report/meanderhr_com_shower_dwhr_overview.pdf (accessed on 24 September 2020).

22. Torras, S.; Oliet, C.; Rigola, J.; Oliva, A. Drain water heat recovery storage-type unit for residential housing. Appl. Therm. Eng. 2016, 103, 670-683. [CrossRef]

23. Spriet, J.; McNabola, A. Decentralized drain water heat recovery: A probabilistic method for prediction of wastewater and heating system interaction. Energy Build. 2019, 183, 684-696. [CrossRef]

24. Ni, L.; Lau, S.; Li, H.; Zhang, T.; Stansbury, J.S.; Shi, J.; Neal, J. Feasibility study of a localized residential grey water energy-recovery system. Appl. Therm. Eng. 2012, 39, 53-62. [CrossRef]

25. Chen, W.; Liang, S.; Guo, Y.; Cheng, K.; Gui, X.; Tang, D. Investigation on the thermal performance and optimization of a heat pump water heater assisted by shower waste water. Energy Build. 2013, 64, 172-181. [CrossRef]

26. Pochwat, K.; Kordana-Obuch, S.; Starzec, M.; Piotrowska, B. Financial Analysis of the Use of Two Horizontal Drain Water Heat Recovery Units. Energies 2020, 13, 4113. [CrossRef] 
27. Zaloum, C.; Lafrance, M.; Gusdorf, J. Drain Water Heat Recovery Characterization and Modeling; Sustainable Buildings and Communitiues: Ottawa, ON, Canada, 2007.

28. Słyś, D.; Kordana, S. Financial analysis of the implementation of a Drain Water Heat Recovery unit in residential housing. Energy Build. 2014, 71. [CrossRef]

29. Bott, T.R. Fouling of Heat Exchangers; Elsevier: Amsterdam, The Netherlands, 1995. [CrossRef]

30. Velan, D. Cost Competitive Horizontal Drain Water Heat Recovery-An opportunity to save energy in many homes and commercial buildings. In Proceedings of the ACEEE Hot Water Forum, Portland, OR, USA, 26-28 February 2017. Available online: https://www.aceee.org/sites/default/files/pdf/conferences/hwf/2017/Velan_Session4C_HWF17_2.28.17.pdf

31. De Paepe, M.; Theuns, E.; Lenaers, S.; Van Loon, J. Heat recovery system for dishwashers. Appl. Therm. Eng. 2003, 23, 743-756. [CrossRef]

32. Wemhoff, A.; Dai, T.; Fleischer, A. The Potential for Thermal Waste Energy Recovery in Industrial Kitchens. In Proceedings of the ASME 2017 International Mechanical Engineering Congress and Exposition, Tampa, FL, USA, 3-9 November 2017; Volume 58417, p. V006T08A039. [CrossRef]

33. Adhikari, P. Feasibility Study of Waste Heat Recovery from Laundry Facility: Case Study-Mr Washing Man Oy. 2017. Available online: http:/ / urn.fi/URN:NBN:fi:amk-201702092213 (accessed on 24 September 2020).

34. Ip, K.; She, K. Waste heat recovery from showers: Case study of a university sport facility in the UK. In Proceedings of the Water Efficiency Conference 2016, Coventry, UK, 7-9 September 2016; Water Efficiency Network, University of Bath: Bath, UK, 2016; pp. 114-121. Available online: http://www.watefnetwork.co.uk/files/default/resources/Conference2016/WatefCon2016_Proce edings.pdf (accessed on 24 September 2020).

35. Dong, J.; Zhang, Z.; Yao, Y.; Jiang, Y.; Lei, B. Experimental performance evaluation of a novel heat pump water heater assisted with shower drain water. Appl. Energy 2015, 154, 842-850. [CrossRef]

36. Baek, N.; Shin, U.; Yoon, J. A study on the design and analysis of a heat pump heating system using wastewater as a heat source. Sol. Energy 2005, 78, 427-440. [CrossRef]

37. Wallin, J.; Claesson, J. Analyzing the efficiency of a heat pump assisted drain water heat recovery system that uses a vertical inline heat exchanger. Sustain. Energy Technol. Assessm. 2014, 8, 109-119. [CrossRef]

38. Postrioti, L.; Baldinelli, G.; Bianchi, F.; Buitoni, G.; Di Maria, F.; Asdrubali, F. An experimental setup for the analysis of an energy recovery system from wastewater for heat pumps in civil buildings. Appl. Therm. Eng. 2016, 102, 961-971. [CrossRef]

39. Wallin, J.; Claesson, J. Investigating the efficiency of a vertical inline drain water heat recovery heat exchanger in a system boosted with a heat pump. Energy Build. 2014, 80, 7-16. [CrossRef]

40. Seybold, C.; Brunk, M. In-house waste water heat recovery. Rehva J. 2013, 6, 18-21.

41. Müller, E.; Schmid, F.; Kobel, B.; Stadtmeister, W. Heizen und Kühlen Mit Abwasser-Ratgeber für Bauträger und KommunenEnergierückgewinnung aus Häuslichem und Kommunalem Abwasser; Deutsche Bundesstiftung Umwelt: Osnabrück, Germany, 2009.

42. Liu, L.; Fu, L.; Jiang, Y. Application of an exhaust heat recovery system for domestic hot water. Energy 2010, 35, 1476-1481. [CrossRef]

43. Todorović, D.; Tomić, M.; Bojanić, R.; Bajatović, D.; Anđelković, A.S. A comparative analysis of a heat pump application with grey wastewater source for domestic hot water preparation in hotels. J. Therm. Anal. Calorim. 2020, 1-14. [CrossRef]

44. Sohail, U.; Kwiatek, C.; Fung, A.S.; Joksimovic, D. Techno-Economic Feasibility of Wastewater Heat Recovery for A Large Hospital in Toronto, Canada. Proceedings 2019, 23, 1. [CrossRef]

45. Spriet, J.; McNabola, A. Decentralized drain water heat recovery from commercial kitchens in the hospitality sector. Energy Build. 2019, 194, 247-259. [CrossRef]

46. Wanner, O. Biofilms Hamper Heat Recovery. Eawag News 2006, 7, 31-32.

47. Liu, Z.; Ma, L.; Zhang, J. Application of a heat pump system using untreated urban sewage as a heat source. Appl. Therm. Eng. 2014, 62, 747-757. [CrossRef]

48. Zhao, X.; Fu, L.; Zhang, S.; Jiang, Y.; Lai, Z. Study of the performance of an urban original source heat pump system. Energy Convers. Manag. 2010, 51, 765-770. [CrossRef]

49. Cipolla, S.S.; Maglionico, M. Heat recovery from urban wastewater: Analysis of the variability of flow rate and temperature in the sewer of Bologna, Italy. Energy Procedia 2014, 45, 288-297. [CrossRef]

50. Sievers, J.; Londong, J.; Stübler, A.; Bestenlehner, D.; Drück, H.; Schönfelder, W. Heat recovery potential of domestic grey water in the pilot project Jenfelder Au in Hamburg. In Proceedings of the 17th International EWA Symposium "WatEnergyResourcesWater, Energy and Resources: Innovative Options and Sustainable Solutions", Munich, Germany, 5-9 May 2014

51. Guo, X.; Hendel, M. Urban water networks as an alternative source for district heating and emergency heat-wave cooling. Energy 2018, 145, 79-87. [CrossRef]

52. Parker, E.; Germain, A.S.; Laurent, E.S. A Study of Waste Water Energy Recovery and Its Implementation in the Commonwealth of Massachusetts. Sponsor: Massachusetts Department of Energy Resources Green Communities Division \& Renewable and Alternative Energy Development. 2013. Available online: https://web.wpi.edu/Pubs/E-project/Available/E-project-101713-17 4945/unrestricted/WWER_IQP_Final_Report_Parker_St_Germain_St_Laurent.pdf (accessed on 26 September 2020).

53. Hrabová, K.; Hrdlička, T.; Tlašek, M. Use of Heat from Wastewater. In Proceedings of the IOP Conference Series: Earth and Environmental Science, Malang City, Indonesia, 12-13 March 2019; Volume 290, p. 012095. [CrossRef] 
54. Pamminger, F.; Scott, D.; Aye, L.; Jelbert, R. Heat energy recovery potential from sewers in Melbourne. Water J. Aust. Water Assoc. 2013, 40, 68. [CrossRef]

55. Oesterholt, F.; Jan, H. Feasibility of Small Scale Heat Rrecovery from Sewers, BTO 2015.208(s) 2014. Available online: http://www.denewa.eu/websites/implementatie/mediadepot/29128bc9e1a2.pdf (accessed on 24 September 2020).

56. The Swiss Federal Council. Water Protection Ordinance of 28 October 1998 (As of 1 April 2020). 2014. Available online: https://www.fedlex.admin.ch/eli/cc/1998/2863_2863_2863/en (accessed on 1 October 2020).

57. Tuncay, E. The Effect of Wastewater Treatment Plant Effluent on Water Temperature, Macroinvertebrate Community, and Functional Feeding Groups Structure in the Lower Rouge River, Michigan. Ph.D. Thesis, University of Michgan-Dearbon, Dearborn, MI, USA, 2016.

58. Pabi, S.; Amarnath, A.; Goldstein, R.; Reekie, L. Electricity use and management in the municipal water supply and wastewater industries. Electr. Power Res. Institute Palo Alto 2013, 194. Available online: https:/ /www.waterrf.org/research/projects/electricit y-use-and-management-municipal-water-supply-and-wastewater-industries (accessed on 26 September 2020).

59. Stillwell, A.S.; Hoppock, D.C.; Webber, M.E. Energy recovery from wastewater treatment plants in the United States: A case study of the energy-water nexus. Sustainability 2010, 2, 945-962. [CrossRef]

60. Kollmann, R.; Maier, S.; Shahzad, K.; Kretschmer, F.; Neugebauer, G.; Stoeglehner, G.; Ertl, T.; Narodoslawsky, M. Waste water treatment plants as regional energy cells-evaluation of economic and ecologic potentials in Austria. Chem. Eng. 2014, 39. [CrossRef]

61. Đurđević, D.; Balić, D.; Franković, B. Wastewater heat utilization through heat pumps: The case study of City of Rijeka. J. Clean. Prod. 2019, 231, 207-213. [CrossRef]

62. Chae, K.J.; Kang, J. Estimating the energy independence of a municipal wastewater treatment plant incorporating green energy resources. Energy Convers. Manag. 2013, 75, 664-672. [CrossRef]

63. Pochwała, S.; Kotas, P. Possibility of obtaining wastewater heat from a sewage treatment plant by the means of a heat pump-A case study. E3S Web Conf. 2018, 44, 00144. [CrossRef]

64. Spriet, J.; Hendrick, P. Wastewater as a heat source for individual residence heating: A techno-economic feasibility study in the brussels capital region. J. Sustain. Dev. Energy Water Environ. Syst. 2017, 5, 289-308. [CrossRef]

65. Stec, A.; Kordana, S. Analysis of profitability of rainwater harvesting, gray water recycling and drain water heat recovery systems. Resour. Conserv. Recycl. 2015, 105, 84-94. [CrossRef]

66. Eslami-nejad, P.; Bernier, M. Impact of grey water heat recovery on the electrical demand of domestic hot water heaters. In Proceedings of the 11th IBPSA Conference, Glasgow, Scotland, 27-30 July 2009. Available online: http://ibpsa.org/proceedings/ BS2009/BS09_0681_687.pdf (accessed on 24 September 2020).

67. Tanha, K.; Fung, A.S.; Kumar, R. Performance of two domestic solar water heaters with drain water heat recovery units: Simulation and experimental investigation. Appl. Therm. Eng. 2015, 90, 444-459. [CrossRef]

68. Gavilán del Amo, A.; López Alonso, A. Drain water heat recovery in a residential building. Master's Thesis, University of Gävle, Gävle, Sweden, 2015. Available online: https://www.diva-portal.org/smash/get/diva2:825938/FULLTEXT01.pdf (accessed on 24 September 2020).

69. Juhošová, D.; Peráčková, J.; Krafčik, M. Recovery of waste heat from the sewer system in the sanitary equipment of a sport complex. In Proceedings of the 2019 7th International Youth Conference on Energy (IYCE), Bled, Slovenia, 3-6 July $2019 ;$; pp. 1-7. [CrossRef]

70. Meggers, F.; Leibundgut, H. The potential of wastewater heat and exergy: Decentralized high-temperature recovery with a heat pump. Energy Build. 2011, 43, 879-886. [CrossRef]

71. Chao, S.; Yiqiang, J.; Yang, Y.; Shiming, D.; Xinlei, W. A field study of a wastewater source heat pump for domestic hot water heating. Build. Serv. Eng. Res. Technol. 2013, 34, 433-448. [CrossRef]

72. Alnahhal, S.; Spremberg, E. Contribution to exemplary in-house wastewater heat recovery in Berlin, Germany. Procedia Cirp 2016, 40, 35-40. [CrossRef]

73. Kayo, G.; Martinac, I.; Shukuya, M.; Rahimibaroughi, H. Heat Recovery from Waste-Water in Buildings-A System-Oriented Longitudinal Study. 2018. Available online: https:/ /www.e2b2.se/library/4982/vaermeaatervinning-ur-byggnaders-spillvattenslutrapport.pdf (accessed on 24 September 2020).

74. Cautley, D. Drain Water Heat Recovery-A Field Study of Commercial Applications; Technical Report; Energy Center of Wisconsin. 2013. Available online: https://www.greenbuildingadvisor.com/app/uploads/2018/11/Dan-C_DWHR-COM_272-1.pdf (accessed on 24 September 2020).

75. Salih, T.W.M. Sewage water heat recovery: A study as an application of energy saving in IRAQ. J. Eng. Sustain. Dev. 2017, 21, 114-123.

76. Yaxiu, G.; Huqiu, D.; Yu, G.; Huanjuan, Z. The potential of urban wastewater heat: The feasibility analysis of using wastewater source heat pump. In Proceedings of the 2011 International Symposium on Water Resource and Environmental Protection, Xi'an, China, 20-22 May 2011; Volume 2, pp. 1481-1484. [CrossRef]

77. Chae, K.J.; Ren, X. Flexible and stable heat energy recovery from municipal wastewater treatment plants using a fixed-inverter hybrid heat pump system. Appl. Energy 2016, 179, 565-574. [CrossRef]

78. Cho, Y.; Yun, R. A raw water source heat pump air-conditioning system. Energy Build. 2011, 43, 3068-3073. [CrossRef] 
79. Meinzinger, F.; Oldenburg, M. Characteristics of source-separated household wastewater flows: A statistical assessment. Water Sci. Technol. 2009, 59, 1785-1791. [CrossRef]

80. Lerch, W.; Heinz, A. Heat recovery from waste water in Low-Energy and Passive Houses: Potentials and concepts in combination with solar thermal energy and heat pumps. In Proceedings of the Task 44 Meeting 3, Barcelona, Spain, 7-8 April 2011.

81. Blokker, E.; Vreeburg, J.; Van Dijk, J. Simulating residential water demand with a stochastic end-use model. J. Water Resour. Plan. Manag. 2010, 136, 19-26. [CrossRef]

82. Hadengue, B.; Scheidegger, A.; Morgenroth, E.; Larsen, T.A. Modeling the water-energy nexus in households. Energy Build. 2020, 225, 110262. [CrossRef]

83. Bailey, O.; Zlatanovic, L.; van der Hoek, J.P.; Kapelan, Z.; Blokker, M.; Arnot, T.; Hofman, J. A Stochastic Model to Predict Flow, Nutrient and Temperature Changes in a Sewer under Water Conservation Scenarios. Water 2020, 12, 1187. [CrossRef]

84. Hendron, R.; Engebrecht, C. Building America Research Benchmark Definition: Updated December 2009. 2010. Available online: https: / / www.nrel.gov/docs / fy10osti/47246.pdf (accessed on 26 September 2020).

85. Kretschmer, F.; Simperler, L.; Ertl, T. Analysing wastewater temperature development in a sewer system as a basis for the evaluation of wastewater heat recovery potentials. Energy Build. 2016, 128, 639-648. [CrossRef]

86. Schilperoort, R.; Clemens, F. Fibre-optic distributed temperature sensing in combined sewer systems. Water Sci. Technol. 2009, 60, 1127-1134. [CrossRef]

87. Wu, R.; Sun, D.; Ma, G. The parameters characteristics on the urban sewage as a cold and heat source and the evaluation on application methods. Renew. Energy 2005, 5, 39-43.

88. Abdel-Aal, M. Modelling the Viability of Heat Recovery from Underground Pipes. Deterministic Modelling of Wastewater Temperatures in a 3000 Sewer Pipe Network. Ph.D. Thesis, University of Bradford, Bradford, UK, 2015. Available online: https:/ / bradscholars.brad.ac.uk/handle/10454/14467 (accessed on 28 September 2020).

89. Koch, M.; Nietlisbach, A.; Känel, B.; Calderoni, M.; Wille, B.; Müller, R.; Bretscher, P.; Wanner, O.; Siegrist, H.; Peter, A.; et al. Heizen und Kühlen mit Abwasser_Leitfaden für die Planung, Bewilligung und Realisierung von Anlagen zur Abwasserenergienutzung; Amt für Abfall, Wasser, Energie und Luft des Kantons Zürich: Zürich, Switzerland, 2010.

90. Merkblatt, D. Energie aus Abwasser-Wärme-und Lageenergie. 2009. Available online: https://de.dwa.de/de/regelwerksankue ndigungen-volltext/abwasserw\%C3\%A4rmenutzung-1990.html (accessed on 26 September 2020).

91. Dürrenmatt, D.J.; Wanner, O. TEMPEST: Computer Program for the Simulation of the Wastewater Temperature in Sewers. Available online: https://www.eawag.ch/fileadmin/Domain1/Abteilungen/eng/software/tempest/tempest_manual_V1_02 .pdf (accessed on 28 September 2020).

92. Dürrenmatt, D.J. Berechnung des Verlaufs der Abwassertemperatur im Kanalisationsrohr. Master's Thesis, Eidgenössische Technische Hochschule Zürich, Zürich, Switzerland, 2006. [CrossRef]

93. Dürrenmatt, D.J.; Wanner, O. A mathematical model to predict the effect of heat recovery on the wastewater temperature in sewers. Water Res. 2014, 48, 548-558. [CrossRef]

94. Ali, S.; Gillich, A. Determining the UK's potential for heat recovery from wastewater using steady state and dynamic modellingpreliminary results. In Proceedings of the 2nd Global Conference on Energy and Sustainable Development, GCESD2018, Edinburgh, UK, 18-20 December 2018. [CrossRef]

95. Elías-Maxil, J.A.; Hofman, J.; Wols, B.; Clemens, F.; van der Hoek, J.P.; Rietveld, L. Development and performance of a parsimonious model to estimate temperature in sewer networks. Urban Water J. 2017, 14, 829-838. [CrossRef]

96. Hofman, J.; Bloemendal, M.; Wols, B.; Agudelo-Vera, C.; Elias Maxil, J.; Boderie, P.; Nijman, M.; Van Der Hoek, J.P. Modelling of Thermal Energy Balance in Sewer Systems. 2014. Available online: http:/ / resolver.tudelft.nl/uuid:e31f2cc8-a39b-49a2-bd41-c0 685bea369d (accessed on 28 September 2020).

97. Sitzenfrei, R.; Hillebrand, S.; Rauch, W. Investigating the interactions of decentralized and centralized wastewater heat recovery systems. Water Sci. Technol. 2017, 75, 1243-1250. [CrossRef]

98. Abdel-Aal, M.; Smits, R.; Mohamed, M.; De Gussem, K.; Schellart, A.; Tait, S. Modelling the viability of heat recovery from combined sewers. Water Sci. Technol. 2014, 70, 297-306. [CrossRef] [PubMed]

99. Saagi, R.; Arnell, M.; Reyes, D.; Sehlén, R.; Jeppsson, U. Modelling heat transfer in sewer systems-Towards a city-wide model for heat recovery from wastewater. In Proceedings of the 10th IWA Symposium on Modelling and Integrated Assessment (Watermatex 2019), Copenha-gen, Denmark, 1-4 September 2019. Available online: http:/ / urn.kb.se/ resolve?urn=urn:nbn:se:ri: diva-42436 (accessed on 28 September 2020).

100. Abdel-Aal, M.; Tait, S.; Mohamed, M.; Schellart, A. Using Long Term Simulations to Understand Heat Transfer Processes during Steady Flow Conditions in Combined Sewers. Water 2021, 13, 570. [CrossRef]

101. Escalas-Cañellas, A.; Ábrego-Góngora, C.J.; Barajas-López, M.G.; Houweling, D.; Comeau, Y. A time series model for influent temperature estimation: Application to dynamic temperature modelling of an aerated lagoon. Water Res. 2008, 42, 2551-2562. [CrossRef] [PubMed]

102. Abdel-Aal, M.; Mohamed, M.; Smits, R.; Abdel-Aal, R.; De Gussem, K.; Schellart, A.; Tait, S. Predicting wastewater temperatures in sewer pipes using abductive network models. Water Sci. Technol. 2015, 71, 89-96. [CrossRef]

103. Golzar, F.; Nilsson, D.; Martin, V. Forecasting wastewater temperature based on artificial neural network (ANN) technique and monte carlo sensitivity analysis. Sustainability 2020, 12, 6386. [CrossRef] 
104. Ip, K.; She, K.; Adeyeye, K. Life-cycle impacts of shower water waste heat recovery: Case study of an installation at a university sport facility in the UK. Environ. Sci. Pollut. Res. 2018, 25, 19247-19258. [CrossRef]

105. Schestak, I.; Spriet, J.; Styles, D.; Williams, A.P. Emissions down the drain: Balancing life cycle energy and greenhouse gas savings with resource use for heat recovery from kitchen drains. J. Environ. Manag. 2020, 271, 110988. [CrossRef]

106. Head, M.; Oleszkiewicz, J. Bioaugmentation for nitrification at cold temperatures. Water Res. 2004, 38, 523-530. [CrossRef]

107. Sedory, P.; Stenstrom, M. Dynamic prediction of wastewater aeration basin temperature. J. Environ. Eng. 1995, 121, 609-618. [CrossRef]

108. Ford, D.; Chih, S.; Sobosta, E. Temperature prediction in activated sludge basins using mechanical screens. In Proceedings of the 27th Industrial Waste Conference, Lafayette, Indiana, 2-4 May 1972; Volume 27, p. 587.

109. Lippi, S.; Rosso, D.; Lubello, C.; Canziani, R.; Stenstrom, M. Temperature modelling and prediction for activated sludge systems. Water Sci. Technol. 2009, 59, 125-131. [CrossRef]

110. Wanner, O.; Panagiotidis, V.; Clavadetscher, P.; Siegrist, H. Effect of heat recovery from raw wastewater on nitrification and nitrogen removal in activated sludge plants. Water Res. 2005, 39, 4725-4734. [CrossRef]

111. Lotti, T.; Kleerebezem, R.; Van Loosdrecht, M. Effect of temperature change on anammox activity. Biotechnol. Bioeng. 2015, 112, 98-103. [CrossRef]

112. Brehar, M.A.; Varhelyi, M.; Cristea, V.M.; Cristiu, D.; AGACHI, Ş.P. Influent temperature effects on the activated sludge process at a municipal wastewater treatment plant. Stud. Univ. Babes Bolyai Chem. 2019, 64. [CrossRef]

113. Abdel-Aal, M.; Villa, R.; Jawiarczyk, N.; Alibardi, L.; Jensen, H.; Schellart, A.; Jefferson, B.; Shepley, P.; Tait, S. Potential influence of sewer heat recovery on in-sewer processes. Water Sci. Technol. 2019, 80, 2344-2351. [CrossRef]

114. Simperler, L. Impact of Thermal Use of Wastewater in a Sewer on the Inlet Temperature of a Wastewater Treatment Plant. Master's Thesis, University of Natural Resources and Life Sciences, Vienna, Austria, 2015. Available online: https://abstracts.bo ku.ac.at/download.php?dataset_id=12640\&property_id=107 (accessed on 28 September 2020).

115. Bundesrat, S. Gewässerschutzverordnung (GSchV). [Swiss Water Protection Act]. 1998. Available online: https://www.admin.ch /gov/de/start/dokumentation/medienmitteilungen.msg-id-3074.html (accessed on 1 October 2020).

116. Council of the City of Vancouver Canada. Energy Utility System By-Law No. 9552. 2020. Available online: https://bylaws.vanco uver.ca/9552c.pdf (accessed on 26 September 2020). 